University of New Hampshire

University of New Hampshire Scholars' Repository

6-15-2020

\title{
Pearl River Negotiation Simulation: Negotiating the Future of Dams
}

\author{
Natallia Leuchanka Diessner \\ University of New Hampshire, nhe4@wildcats.unh.edu \\ Catherine Ashcraft \\ University of New Hampshire, catherine.ashcraft@unh.edu \\ Weiwei Mo \\ University of New Hampshire, weiwei.mo@unh.edu \\ Cuihong Song \\ University of New Hampshire
}

Follow this and additional works at: https://scholars.unh.edu/nh_epscor

\section{Recommended Citation}

Diessner, Natallia Leuchanka, Ashcraft, Catherine M., Mo, Weiwei, and Song, Cuihong. 2020. "Pearl River Negotiation Simulation: Negotiating the Future of Dams". University of New Hampshire, Durham. doi: https://dx.doi.org/10.34051/p/2020.394

This Report is brought to you for free and open access by the Research Institutes, Centers and Programs at University of New Hampshire Scholars' Repository. It has been accepted for inclusion in New Hampshire EPSCoR by an authorized administrator of University of New Hampshire Scholars' Repository. For more information, please contact Scholarly.Communication@unh.edu. 


\title{
Pearl River Negotiation Simulation: Negotiating the Future of Dams
}

\author{
Teaching Packet
}

This is a seven-party, facilitated, multi-issue negotiation simulation for eight or nine participants about the management of dams in a coastal basin. The complete simulation includes the following materials:

1. Teaching notes.

2. Presentation slides and video recording (available at: https://scholars.unh.edu/nh_epscor/3/) introducing the role-play and the system dynamics model.

3. Link to the web-based System Dynamics Model Application (available online at: https://ddc.unh.edu/dam-system-dynamics/)

4. Table place cards for each role (can be printed, folded in half, and displayed at the negotiating table).

5. General Instructions for all players, which describe the setting of the Pearl River Basin, provide details on the status of the five dams in the basin, and outline the three decisions to be negotiated.

6. Confidential Instructions for each role, which provide background information about the role's specific interests and constraints and a worksheet to assist in the negotiation. To help maintain the usefulness of the role-play, please share the confidential instructions only as needed to implement the role-play.

To allow for easy printing and use of each of the above materials, page numbers in this Teaching Packet restart with each section and are not continuous throughout the entire document.

(C) 2020, University of New Hampshire, All rights reserved.

This case was written by Natallia Leuchanka Diessner, Dr. Catherine M. Ashcraft, Dr. Weiwei Mo, and Cuihong Song at the University of New Hampshire (UNH), Durham, NH, USA. William Winslow of the UNH Data Discovery Center helped with developing the web-based user interface. This case was developed with funding provided by the National Science Foundation's Research Infrastructure Improvement (NSF \#IIA-1539071). For further information, including licensing and permissions, please contact UNHInnovation at unh.innovation@unh.edu.

Suggested citation:

Diessner, Natallia Leuchanka, Ashcraft, Catherine M., Mo, Weiwei, and Song, Cuihong. 2020. "Pearl River Negotiation Simulation: Negotiating the Future of Dams." University of New Hampshire, Durham. https://dx.doi.org/10.34051/p/2020.394 


\title{
Pearl River Negotiation Simulation: Negotiating the Future of Dams
}

\author{
Teaching Notes
}

\section{Overview}

The Pearl River negotiation simulation is a facilitated, multi-issue negotiation simulation for eight or nine participants about the management of five dams in the hypothetical Pearl River basin. This science-based role-play negotiation simulation provides an opportunity for learning about and discussing larger-scale management of ecosystems, use of scientific data and modeling in environmental decision-making under uncertainty, and consensus-based negotiations over water resources. This role-play simulation includes the Pearl River system dynamics model application, which simulates environmental and economic outcomes under different dam management alternatives. The Pearl River system dynamics model user interface can be accessed at: https://ddc.unh.edu/dam-system-dynamics/.

\section{Intended Audience}

The intended audience includes graduate and undergraduate students, as well as practitioners and professionals engaged in decisions about dams, such as local, regional, and federal government entities, national and local non-profit organizations, homeowner associations and other types of community groups, and dam owners and hydropower operators.

\section{Key lessons}

- Sustainable solutions to conflicts over dams meet multiple stakeholders' interests and receive broad political, community, and financial support for implementation.

- Dam decisions are multi-issue negotiations that involve linked social and ecological systems, feedbacks over spatial and temporal scales, many stakeholders, overlapping legal and procedural frameworks, and scientific uncertainty.

- The most successful dam decisions pay careful attention to preparation, including ensuring the right parties participate, are prepared, and interact throughout to bring both expert and local/experiential knowledge to bear on the decision.

- A negotiation agenda should include opportunities for stakeholders to share information about quantifiable interests and non-quantifiable interests, time to brainstorm multiple alternatives and develop new alternatives, and time to agree on performance criteria for deciding between alternatives.

- Linking decisions across multiple dams within a river system can expand the range of alternatives available to meet multiple interests and optimize across social, economic, and environmental tradeoffs, as compared to making decisions about a single dam at a time.

- Dam decisions should be informed by credible scientific data about the likely impacts of decisions. A system dynamics model can provide information about the likely impacts of choices, such as how the decision to focus on one dam or a series of dams will affect outcomes for fish, cost, and hydropower generation.

- A neutral party can provide critical process management services before, during, and after decisions. 
- Role-play negotiations create opportunities for participants to experience dam decisions from another stakeholder's perspective.

- Role-play negotiations create opportunities for participants to develop policy innovations.

\section{Scenario Description}

The Pearl River basin is a coastal basin that includes the Pearl River and its tributary, the Mill Creek. Multiple stakeholders with diverse interests and concerns are interested in the dam-related issues in the basin. There are three hydropower dams on the Pearl River and two nonhydropower dams on Mill Creek. All dams have varying levels of fish passage, ranging from no passage to adequate passage. Dam A on Mill Creek is owned by the Town of Allen and has recently received a Notice of Public Safety from the State Water Resources Division (State WRD). The town must decide how to address the Notice and whether it makes sense to consider the future of other dams in the Pearl River basin as it makes its decision. State WRD invited representatives from six other stakeholder groups to participate in a Working Group (for a total of seven stakeholder groups): the Federal Agency of Natural Resources (Federal ANR), the Historic Preservation Agency of the State (State Historic), Rivers-R-Us (an environmental nongovernmental, non-profit organization), the Allen Pond Homeowners Association (representing property owners along Allen Pond, the impoundment created by Dam A), HydroEnergy, LLC. (the hydropower developer which owns the three hydropower dams on the Pearl River), and the Town of Allen (which owns two non-hydropower dams on Mill Creek). The Working Group also includes one or two facilitators who will help manage the meeting. The main goal of the meeting is to develop a "Work Plan" for the future of Dam A and possibly for the other dams in the Pearl River basin. To support the Group's efforts, a local university developed and shared a novel system dynamics model, which simulates the impacts of different decisions on fish populations, hydropower generation, and project cost. Negotiators can access the model during the negotiation via a web-user interface. The Working Group looks forward to using the model to find agreement on the following three decisions:

1. Which dams should be included in the Work Plan and what dam management alternatives should be considered?

2. Who is responsible for implementing the Work Plan?

3. Who pays to implement the Work Plan?

The municipal, state, and federal officials have indicated they aim to act on the Work Plan if at least six out of the seven stakeholders support the agreement. If fewer than six stakeholders support the recommendations, the Town of Allen will decide on its own about next steps to respond to Dam A's notice of deficiency.

\section{Logistics}

\section{A. Preparation and Planning}

\section{Participants and group size}

The role-play negotiation is best played with eight or nine people: one person for each negotiating role and one or two facilitators. If there are enough participants, the facilitator's role should be doubled up and one facilitator should oversee the process and the other facilitator should run the web-based system dynamics model during the negotiation. If there are more participants than available roles, two participants can double up and play any other role. If 
stakeholders involved in dam decisions are participating in the role-play negotiation simulation, they should be assigned to play a role different than their actual role.

Ideally, the General and Confidential Instructions should be distributed in advance (a week to a few days before the simulation). If not possible or if the negotiation simulation coordinator cannot be sure who will be present for the negotiation, the General and Confidential Instructions should be distributed on the day of the simulation and players should have at least 60 minutes to read. The General Instructions describe the setting of the Pear River basin and its five dams and provide details about the decisions to be made. The information in the General Instructions is common knowledge, i.e. known to all participants. The Confidential Instructions provide information specific to each role. Participants should not show the Confidential Instructions to one another, although they may choose to verbally share any information they want during the negotiations.

\section{Materials}

The following materials will be useful for running the negotiation simulation:

- PowerPoint presentation slides and video recording introducing the role-play and the system dynamics model. A video recording of the introductory PowerPoint presentation can be accessed here: https://scholars.unh.edu/nh_epscor/3/.

- Table place cards for each of the roles to be displayed at the negotiating table.

- General Instructions for all negotiators, which includes the link to the web-based system dynamics model user interface.

- Confidential Instructions for each negotiator and pens or pencils to fill out the included worksheets.

- Materials for the facilitator to make notes that are visually accessible to all negotiators, such as a flip chart or dry erase board, and markers.

- Internet connection that is strong enough to accommodate at least one computer running the system dynamics model per negotiating group. It is useful, but not necessary, for each participant to have access to an individual, internet-connected device to explore the system dynamics model. ${ }^{1}$

- Computer or tablet for the facilitator to run the system dynamics model and ability to display results for all participants to see, for example using a projector or large monitor.

- Extension cords and charging stations to accommodate the computers and tablets used throughout the negotiation.

This teaching package describes materials and logistics for a face-to-face negotiation, which can be readily adapted to a virtual negotiation setting. If the negotiation is held virtually, it will be important the facilitator is able to share their screen so all negotiators can see notes and outputs of scenarios the group tries out using the system dynamics model.

\footnotetext{
${ }^{1}$ Note: If more than 80 computers will be using the web-based system dynamics model at the same time, please contact the UNH Data Discovery Center (using this link: https://ddc.unh.edu/contact/) in advance to ensure sufficient bandwidth will be available.
} 


\section{$\underline{\text { Room set-up }}$}

If more than one group will be negotiating at the same time a larger room with a projector is useful for displaying the pre-negotiation introductory PowerPoint presentation, which includes a demonstration of the system dynamics model user interface. Separate rooms or spaces are useful for the groups to negotiate independently. Negotiators should be able to sit so they can see one another, see any notes the facilitator records, and see the display of the system dynamics model results. Each negotiating group should have access to a computer or tablet and be able to display the web-based user interface.

\section{B. Flow of the Pearl River Negotiation Simulation}

Without any pre-negotiation preparation, the Pearl River negotiation simulation will take 4-4.5 hours. The total time can be reduced to 3.5 hours if participants are able to read the General and Confidential Instructions and review the web-based user interface ahead of time. If participants read their Confidential Instructions ahead of time, it is still recommended they have time to review on the day of the simulation. Descriptions of each step are provided below.

\begin{tabular}{ll}
\hline Steps & $\begin{array}{l}\text { Recommended Time } \\
\text { Allotment }\end{array}$ \\
\hline (1) Read and review General Instructions & 30 minutes* \\
\hline (2) Read and review Confidential Instructions & 20 minutes* \\
\hline (3) Introductory Presentation & 20 minutes \\
\hline (4) Explore the system dynamics model (SDM) web- & 20 minutes* \\
based user interface & 20 minutes \\
\hline (5) Same-role group discussions & 2 hours, 30 minutes \\
\hline (6) Negotiations & 45 minutes - 1 hour \\
\hline (7) Debriefing & These steps can take place in advance if the organizer is confident participants will show up.
\end{tabular}

Step 1: Read and review General Instructions (30 minutes)

The General Instructions describe the Pear River basin setting, details about each of the five dams in the basin, and information about the Working Group's decisions. Players should have at least 30 minutes to read the General Instructions, if reading on the day of the simulation.

\section{Step 2: Read and review Confidential Instructions (20 minutes)}

Confidential Instructions should be distributed according to the role each participant is playing. When distributing the Confidential Instructions, the simulation coordinator should remind participants not to show their Confidential Instructions to one another, although they can decide what information they want to share verbally during the negotiation. Participants should review the included worksheet and pay attention to each role's preferred alternative for each of the five dams. Although other good outcomes are possible, the preferred alternative can serve as a guide to the participant of their role's position. Participants can use the worksheets before and during the negotiation to identify scenarios they would like to propose at the negotiating table.

Step 3: Introductory Presentation (20 minutes)

The pre-negotiation introductory PowerPoint presentation can be used to provide an introduction to the context and a demonstration of the system dynamics model web-based user interface. 
Presentation slides are included in this Teaching Packet and can also be viewed on the University of New Hampshire Scholar's Repository via a recorded webinar-style video. The recording may be accessed at: https://scholars.unh.edu/nh_epscor/3/.

Step 4: Explore the system dynamics model (SDM) web-based user interface (20 minutes) Ideally, each participant will have access to an individual tablet or computer to explore the webbased user interface. If not possible, participants can use one device and explore in a small group. If there will be multiple groups negotiating simultaneously, this step can be combined with the same-role group discussions.

\section{Step 5: Same-role group discussions (20 minutes)}

If there will be multiple groups negotiating simultaneously, participants should sit with other participants assigned to the same role to discuss their interests and priorities in the upcoming negotiation, strategize how to best use the system dynamics model and other information, consider whether they want to form coalitions or have private discussions with any of the other roles, and think about what will be the likely outcome if the negotiations fail. If a single group will be negotiating, this step can be skipped, but participants should be instructed to think about these points when preparing for the negotiation simulation.

\section{Step 6: Negotiations (2 hours, 30 minutes)}

If there will be multiple groups negotiating simultaneously, participants should split up into separate negotiating groups so that each role is represented. The facilitator should begin the negotiation by introducing themselves and the nature of the meeting, going over the ground rules, and then asking each participant to introduce their role and priority interests. The group will then have about 15 minutes of unstructured time (participants should stay in their roles) to interact and learn about each other's interests. Participants can also use the time to continue to explore the web-based user interface on their own or try out some scenarios with other participants. Sometimes this networking time will lead to the formation of initial coalitions of participants with similar interests. The facilitator does not have a specific task during this time and can either prepare or interact with the stakeholders.

After the 15 minutes, the facilitator should engage participants in a discussion about their interests around the three decisions outlined in the General Instructions. The facilitator is encouraged to write the participants' interests on a flip chart or dry erase board. A sample format for recording interests is included in the facilitator's Confidential Instructions. It is important for all participants to share their role's interests in this part of the negotiation.

After the interest-sharing session, the facilitator is encouraged to provide participants with a short "working" break, where they can take a break or take additional time to consult with their coalition or any other coalitions. Participants should stay in their roles during the break.

After the break, the facilitator will lead a brainstorming discussion around various alternative agreements for the Work Plan options. Proposed agreements should be complete packages, consisting of an option for each of the three decisions. Two samples agreements are provided in section 6 (pages 7 and 8) of these Teaching Notes. During this time, participants should be encouraged to brainstorm alternative packages, but reserve evaluating them for later. Once 
several packages have been proposed and recorded, the facilitator should encourage participants to use the system dynamics model user interface to evaluate and modify the proposed dam management options for the five dams (Decision 1), as well as the costs associated with each of those options (to inform Decision 3). The facilitator should remind participants to consider Decision 2 and interests the system dynamics model does not quantify. The facilitator should take one or two non-binding votes to help the participants assess whether there is consensus around any of the proposed or modified packages, and then continue facilitating the discussion. At the end of the negotiation, the facilitator should take a final vote and record the details of the package agreement, if the group reached consensus, or no agreement on the recording sheet (included in the facilitator's Confidential Instructions) and share the outcome with the negotiation simulation coordinator.

Step 7: Debriefing (45 minutes to 1 hour)

All participants should reconvene for the debriefing. The debriefing should begin with either posting the outcomes from all groups (the negotiation simulation coordinator may want to use the summary form provided on page 13) or with a verbal report from each facilitator of their group's final agreement. Many negotiated outcomes are possible within the rules of the game, including outcomes the negotiators invent, as long as the outcomes are consistent with the constraints within the negotiators' Confidential Instructions. Two possible agreements are described in section 6 . The debriefing can then be continued using questions in section 7 (page 8).

\section{Sample Work Plan Agreements}

Note: A "package" agreement must specify details for each of the three decisions.

\section{Sample Work Plan \#1}

Decision 1: Include Dam A in combination with other dams in the basin (option 2). Specific decisions for each of the five dams:

- Dam A: repair, add hydropower turbines, install fish lift

- Dam B: add hydropower turbines

- Dam 1: install Denil fishway

- Dam 2: do nothing

- Dam 3: do nothing

Decision 2: Collaborative Study Group (option 2). Include historic mitigation as an objective in the Work Plan with a dedicated designated budget line item. Hire a neutral, third-party facilitator to guide the rest of the decision-making process and any future meetings.

Decision 3: Federal ANR, State WRD, Rivers-R-Us, and HydroEnergy, LLC. contribute direct funding. Federal ANR to contribute $\$ 1,000,000$. State WRD to contribute $\$ 500,000$. Rivers-RUs to contribute $\$ 500,000$. HydroEnergy, LLC. to contribute $\$ 1,265,000$. Town of Allen residents (including Allen HOA) plans to contribute $\$ 300,000$ for Dam A depending on approval by town vote. Town of Allen also provides local Town Planner and GIS services. 
Sample Work Plan \#2

Decision 1: Include Dam A in combination with other dams in the basin (option 2). Specific decisions for each of the five dams:

- Dam A: repair, install nature-like fishway

- Dam B: remove

- Dam 1: install Denil fishway

- Dam 2: do nothing

- Dam 3: do nothing

Decision 2: Collaborative Study Group (option 2). Hire a consultant to conduct a socialecological study.

Decision 3: Federal ANR, State WRD, and Rivers-R-Us contribute direct funding. Federal ANR to contribute $\$ 2,000,000$, Rivers-R-Us to contribute $\$ 1,000,000$, and State WRD to contribute $\$ 500,000$.

\section{Debriefing Questions and Key Lessons}

Below are some useful questions for continuing the debriefing discussion:

1. Did you feel your group was able to reach a successful outcome?

- For groups that feel they were more successful, what factors contributed to a successful outcome?

- For groups that feel they were less successful, what barriers did you notice during the negotiation?

Contrasting the experiences of groups that feel they were more or less successful will reveal a lot about the strategies individual negotiators pursued. Some stakeholders may choose to play their roles by staking out ambitious positions early on and making few concessions about what they want, while others will focus on listening to others' interests and exploring less obvious solutions. Groups that were successful will often reflect on the value of linking the three decisions together and considering both quantifiable and non-quantifiable elements of the dam decisions. Dam decisions have both ecological and social impacts, and feedbacks between the two. Although improving fish passage may be most important for one stakeholder, another may care most about preserving an open viewscape or community identity around an important industrial-era mill associated with the dam, and yet another may be most concerned about fulfilling their regulatory mandate to protect public safety. A negotiation based on interests will include the full diversity of interests and consider options and tradeoffs across these to develop innovative solutions.

Importantly, any groups that did not reach an agreement should be encouraged not to view this outcome as failure, but rather as an interesting opportunity to explore barriers. For example, one negotiator with significant financial resources may have felt their interests were not heard or that another negotiator was too competitive and they therefore decided to withhold their support for the agreement. Or, a stakeholder may have felt they had a strong "Best Alternative To a Negotiated Agreement (BATNA)" and therefore a high likelihood of achieving a preferable outcome if the negotiations fail. 
It is worth reminding the negotiators of the significance of the decision rule, and asking what, if any, effect this had on the outcome. Because support from only six of the seven stakeholders was required for an agreement, any one of the stakeholders could be excluded from the agreement, as long as their financial contribution wasn't needed for the agreement. The decision rule also means that any two negotiators could form a coalition to oppose an agreement (even if they could support the agreement according to their Confidential Instructions) and block the group from getting enough support for any agreement.

A conversation about financial resources, BATNAs, and coalitions is an opportunity to explore the different sources of power that negotiators bring to the negotiation. Often the bases for forming coalitions are having a shared interest in a particular outcome and establishing interpersonal trust.

- Key lessons:

- Sustainable solutions to conflicts over dams meet multiple stakeholders' interests and receive broad political, community, and financial support for implementation.

- Dam decisions are multi-issue negotiations that involve linked social and ecological systems, feedbacks over spatial and temporal scales, many stakeholders, overlapping legal and procedural frameworks, and scientific uncertainty.

2. How did you prepare for the negotiation? In what ways did your preparation influence the outcomes?

Preparation is critical for improving negotiation outcomes and much can be learned from hearing about individual negotiators' strategies for preparation. Negotiators who feel they were less well prepared may have been frustrated by what seemed like their inability to influence the outcome. It is worth asking participants whether there were any opportunities during the negotiation to improve their capacity to participate. For example, sidebar conversations with other stakeholders or the facilitator often provide capacity building opportunities. In other cases negotiators may comment on an open and welcoming tone of the negotiation, which empowered them to ask questions about things they didn't understand.

Good negotiation preparation includes thinking about one's own interests and priorities, thinking about other stakeholders' interests and priorities, thinking about the likely outcome if negotiations fail and for which stakeholders' this outcome would be better or worse, thinking about the resources stakeholders can contribute to the negotiation, familiarizing oneself with the system dynamics model user interface, and preparing different package agreements and rationales for how the packages meet, what the negotiator assumes to be, other stakeholders' interests. Because negotiators enter the negotiations with little information about one another's roles, it is also useful to prepare questions in advance to ask the other stakeholders to learn more. If negotiators did so, ask which questions were most useful. These questions will often begin with common phrases, such as "Why..." and "What if..."

Negotiation preparation also involves decisions about structure, such as who to invite to participate and what decisions to focus on during the negotiation. The range of stakeholders that participate determines what kinds of information and interests are shared during the negotiation, 
including both technical and experiential knowledge. It is valuable to ask negotiators about their experiences interacting with the diverse stakeholders at the table, as well as additional stakeholders they would have liked to engage. If stakeholders who participate in actual dam decisions play the negotiation simulation, the negotiation simulation coordinator can ask how common it is for dam decisions to include opportunities that bring together a diverse group of stakeholders to brainstorm management alternatives and ask about the value of such opportunities.

- Key lesson: The most successful dam decisions pay careful attention to preparation, including ensuring the right parties participate, are prepared, and interact throughout to bring both expert and local/experiential knowledge to bear on the decision.

\section{What happened in your group at the start of the negotiation and after?}

Ask negotiators how they decided with whom they wanted to speak first during the unstructured networking time. Common responses are choosing to speak with others with shared or differing interests, others with significant resources to contribute to implementing the agreement, and the owner of Dam A (the Town of Allen) because of their decision-making authority. Some negotiators will find unexpected value in meeting with stakeholders they initially assumed would have different interests, for example by establishing a relationship for a constructive working relationship and learning about the other negotiator's interests and constraints. Groups that reach outcomes they consider successful will often report open discussions about interests, including both quantifiable interests, such as the impacts of dam decisions on fish population and cost considerations, as well as non-quantifiable interests, such as the impacts of dam decisions on aesthetics, preservation of industrial or pre-industrial history, and community identity. Groups that neglect non-quantifiable interests will find it difficult to engage stakeholders for whom these issues are a priority.

In some groups, all participants will continue to sit together and ask one another questions and listen to the responses. Other groups will immediately split into subgroups with shared interests and may use the system dynamics model to craft initial proposals. Especially if one negotiator feels less comfortable using the system dynamics model or less well prepared for the negotiation, this can also be a useful opportunity to learn from others with shared interests. But, splitting into subgroups can also be a problem if some stakeholders feel left out of a discussion or if different subgroups craft competing proposals and are subsequently inflexible about considering alternatives.

Successful groups will have reserved time for sharing interests and brainstorming different alternatives. It is critical negotiators share information about their interests and spend time proposing new alternatives that meet stakeholders' interests. Although it will be tempting for participants to immediately start evaluating alternatives, by suspending judgment the group can create a more exhaustive set of alternatives. If negotiators work together, many alternative solutions are possible that meet their interests, but negotiators will need to consider all three decisions together. Groups that attempt to reach agreement on only one decision at a time will be frustrated to find the decisions are linked, i.e. what a negotiator can agree to on one decision is linked to the outcome on another. By connecting options across the three decisions, the group 
can craft package agreements that meet the negotiators' different priorities. They can then use the system dynamics model to evaluate the performance of the decision alternatives for the specified quantifiable criteria and discuss likely impacts for other interests, along with options for compensation or mitigation.

- Key lesson: A negotiation agenda should include opportunities for stakeholders to share information about both quantifiable interests and non-quantifiable interests, time to brainstorm multiple alternatives and develop new alternatives and time to agree on performance criteria for deciding between alternatives.

4. How did the information from the system dynamics model about predicted outcomes for the different dam management options inform your discussion?

Discussing how negotiating groups used the system dynamics model will reveal a lot about their efforts to create and claim value. The geographical scale of dam decisions is not pre-determined. Instead, the scale on which to focus is a choice the stakeholders for each decision negotiate. Dam decisions are typically opportunistic and focus on only a single dam. However, expanding the decision scale to include multiple dams within a basin, or even across basins, creates opportunities to benefit more interests.

For groups that feel they reached more successful agreements, it is worth comparing the performance indicators (the results from the system dynamics model for fish populations, hydropower generation, and cost) to the likely outcome if the negotiations fail, which is either to repair or remove Dam A. In these groups, negotiators may have listened carefully to one another's interests, engaged in an exhaustive brainstorming session, and accepted the results of the system dynamics model as objective criteria for evaluating alternative proposals.

For groups that feel they reached less successful outcomes, it is also worth comparing the performance indicators of their agreement and the likely outcomes if negotiations fail. In many cases, the negotiated agreement will outperform the likely outcomes if negotiations fail, but negotiators may still be unhappy with the outcome, for example if they feel other negotiators were too competitive or inflexible. For groups that did not reach agreements, negotiators may have primarily used the model in an adversarial way to develop and propose solutions that met only their own interests and to undermine the solutions proposed by others they viewed as opponents.

- Key lessons:

○ Linking decisions across multiple dams within a river system can expand the range of alternatives available to meet multiple interests and optimize across social, economic, and environmental tradeoffs, as compared to making decisions about a single dam at a time.

- Dam decisions should be informed by credible scientific data about the likely impacts of decisions. A system dynamics model can provide information about the likely impacts of choices, such as how the decision to focus on one dam or a series of dams will affect outcomes for fish, cost, and hydropower generation. 


\section{How was the role of the facilitator helpful during the negotiation?}

A neutral facilitator provides critical process management services. Such services can include pre-negotiation activities, including conducting a stakeholder or conflict assessment to determine which stakeholders should be invited and which issues should be negotiated. In the Pearl River negotiation, participants will commonly report the facilitator was critical for time management, especially for ensuring adequate time for sharing interests, brainstorming, and deal-making, ensuring discussions remained civil and constructive, (i.e. holding participants to the ground rules), facilitating communication and ensuring everyone's perspective was heard, supporting less well prepared negotiators to participate fully, highlighting priority interests, and summarizing emerging areas of consensus.

- Key lesson: A neutral party can provide critical process management services before, during, and after decisions.

If the negotiation simulation is run with stakeholders involved in decisions about dams:

6. What was your experience playing the role of a different stakeholder?

The Pearl River role-play negotiation simulation provides an opportunity for participants to engage in innovative discussions free of the constraints of their actual role. For example, a government regulator can engage in discussions and consider options outside of their usual regulatory constraints. Other stakeholders may find it insightful to experience a negotiation within a government regulator's organizational and legal constraints. Experiencing a negotiation from someone else's perspective can provide an opportunity to develop empathy for others. Although stakeholders can still disagree, they may develop greater understanding for one another's perspective.

- Key lesson: Role-play negotiations create opportunities for participants to experience dam decisions from another party's perspective.

\section{What was your experience brainstorming alternative solutions?}

The Pearl River negotiation simulation can provide an opportunity for stakeholders to consider policy innovations. The hypothetical nature of the role-play allows participants to engage in brainstorming in a way they may otherwise be unwilling or prevented from doing so. And, stakeholders often don't interact until their positions have already solidified into seemingly zerosum opportunities. Engaging in a role-play negotiation simulation early in the negotiation process is an opportunity to consider unconventional solutions that meet the participants' interests.

- Key lesson: Role-play negotiations create opportunities for participants to develop policy innovations. 
Pearl River Negotiation Simulation (Teaching Notes)

Pearl River Negotiation Simulation: Negotiating the Future of Dams Summary Form for All Groups

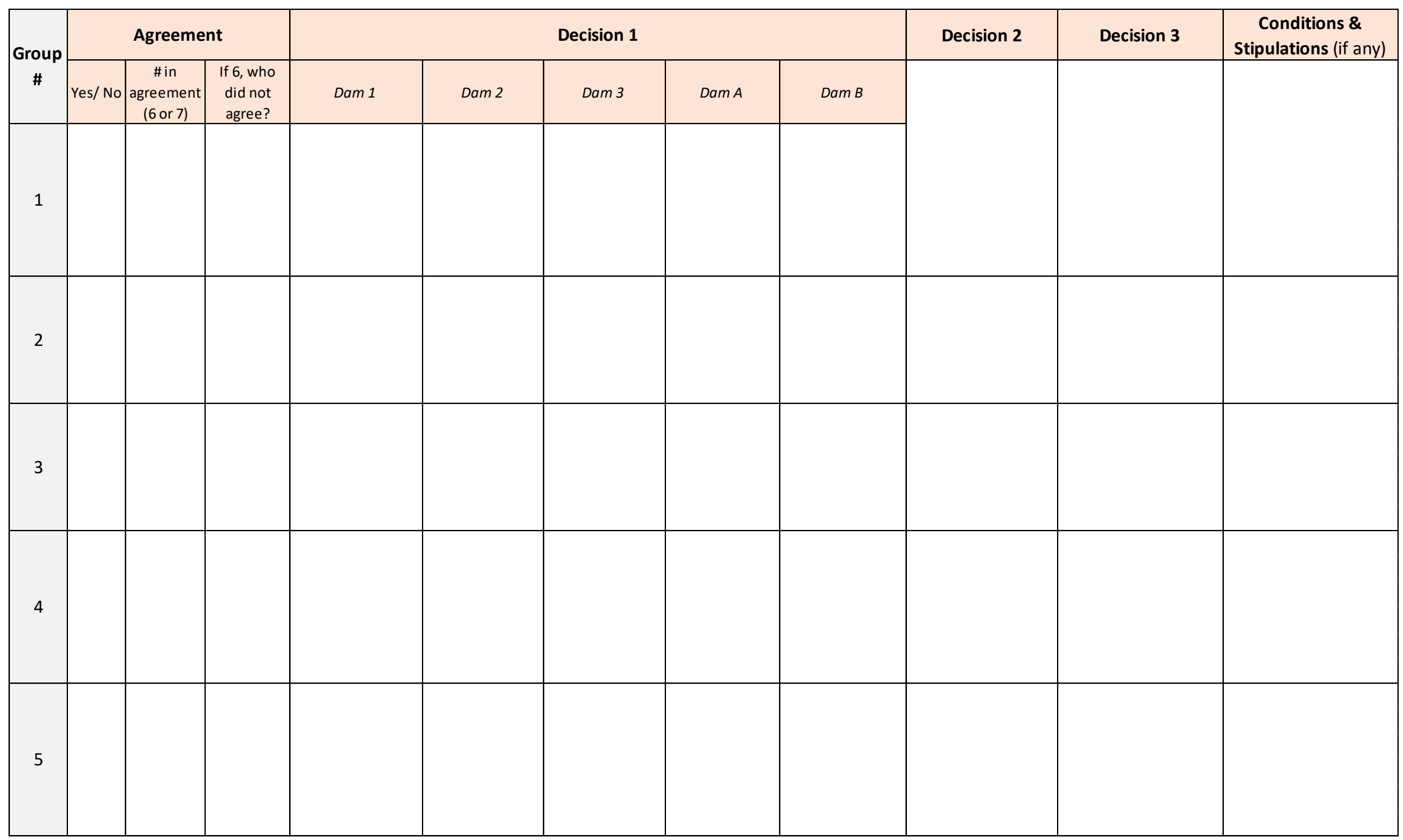

(C) 2020, University of New Hampshire, All rights reserved.

13 


\section{Recommended Further Reading}

- Negotiation and environmental dispute resolution

○ Fisher, J. (2014). Chapter 55: Managing Environmental Conflict. The Handbook of Conflict Resolution. San Francisco, John Wiley \& Sons: 1-21.

○ Fisher, R., Ury, W., \& Patton, B. (2011). Getting to Yes: Negotiating Agreement Without Giving In (3rd ed.). New York: Penguin Books.

- NOAA Coastal Services Center. (2010). Introduction to Planning and

Facilitating Effective Meetings. Charleston, SC. Retrieved from https://coast.noaa.gov/data/digitalcoast/pdf/effective-meetings.pdf

○ Susskind, L., Ashcraft, C. 2010. How to Reach Fairer and More Sustainable Agreements. In J. Dore, J. Robinson, \& M. Smith (Eds.) Negotiate: Reaching agreements over water (pp.59-78). Gland, Switzerland: IUCN.

○ Susskind, L., Levy, P. F., \& Thomas-Larmer, J. (2000). Part 1: The Mutual Gain Approach. In Negotiating environmental agreements: how to avoid escalating confrontation, needless costs, and unnecessary litigation (pp. 17-40).

Washington, D.C.: Island Press.

- The role of science in environmental decision-making

- Adler, P.S. Towards a more humble inquiry: the practice of joint fact-finding. In Joint Fact-Finding in Urban Planning and Environmental Disputes. M. Matsuura and T. Schenk (Eds.). Milton Park, Routledge: 28-42.

○ Karl, H. R., Susskind, L. E., \& Wallace, K. H. (2007). A Dialogue, Not a Diatribe Effective Integration of Science and Policy Through Joint Fact Finding. Environment, 49(1), 20-34. http://doi.org/10.3200/ENVT.49.1.20-34

○ Susskind, L., Field, P., Smith, F. Joint fact-finding: process and practice. In Joint Fact-Finding in Urban Planning and Environmental Disputes. M. Matsuura and T. Schenk (Eds.). Milton Park, Routledge: 14-27.

- Balancing tradeoffs in dammed systems

○ Owen, D., Apse, C., 2014. Trading dams. UCDL Rev. 48, 1043.

○ Roy, S.G., Uchida, E., de Souza, S.P., Blachly, B., Fox, E., Gardner, K., Gold, A.J., Jansujwicz, J., Klein, S., McGreavy, B., 2018. A multiscale approach to balance trade-offs among dam infrastructure, river restoration, and cost. Proceedings of the National Academy of Sciences of the United States of America 115(47), 12069-12074.

○ Song, C., Diessner, N.L., Ashcraft, C.M., Mo, W. Integrating system dynamics modeling and role-play simulation in dam decision-making: A comparison of modeled Pareto-optimal and stakeholder negotiated solutions. Under review.

○ Song, C., Omalley, A., Roy, S.G., Barber, B.L., Zydlewski, J., Mo, W., 2019. Managing dams for energy and fish tradeoffs: What does a win-win solution take? Science of The Total Environment 669(15), 833-843. 


\section{Introductory PowerPoint Presentation (next 9 pages)}

An introductory video of this presentation can be accessed online at: https://scholars.unh.edu/nh_epscor/3/. 
Introduction to the

Science-Based Role-Play Simulation for Engaged Decision-Making: A Dam Negotiation Application

Created by:

Dr. Catherine Ashcraft and Natallia Leuchanka Diessner

Natural Resources \& the Environment, University of New Hampshire

Dr. Weiwei Mo and Cuihong Song

Civil and Environmental Engineering, University of New Hampshire

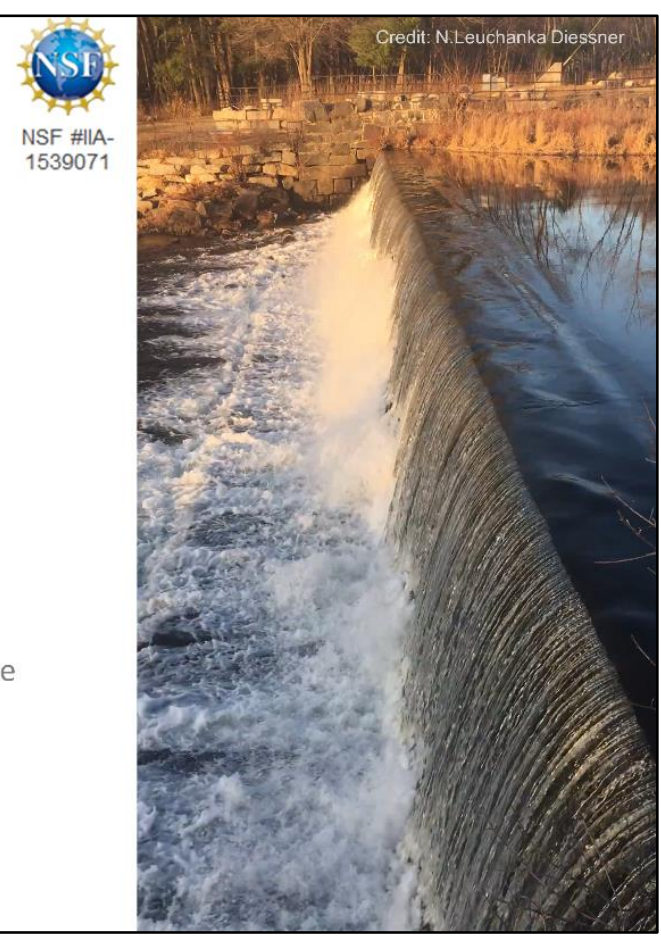

\begin{tabular}{|c|c|c|}
\hline $\begin{array}{l}\text { Dam Negotiation } \\
\text { Simulation } \\
\text { Objectives } \\
\text { Advancing } \\
\text { Sustainability } \\
\text { Science }\end{array}$ & 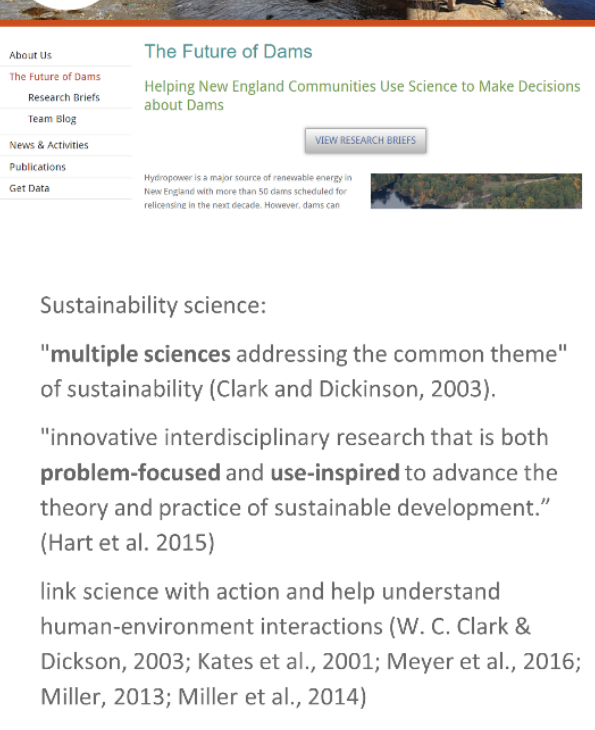 & $\begin{array}{l}\text { - } \quad \text { Linking knowledge with action } \\
\text { - } \quad \text { Co-production of knowledge } \\
\text { about social-ecological systems } \\
\text { - } \quad \text { Stakeholder engagement } \\
\text { - } \quad \text { Place-based knowledge } \\
\text { - Foster interdisciplinary } \\
\text { integration \& organizational } \\
\text { innovation }\end{array}$ \\
\hline
\end{tabular}




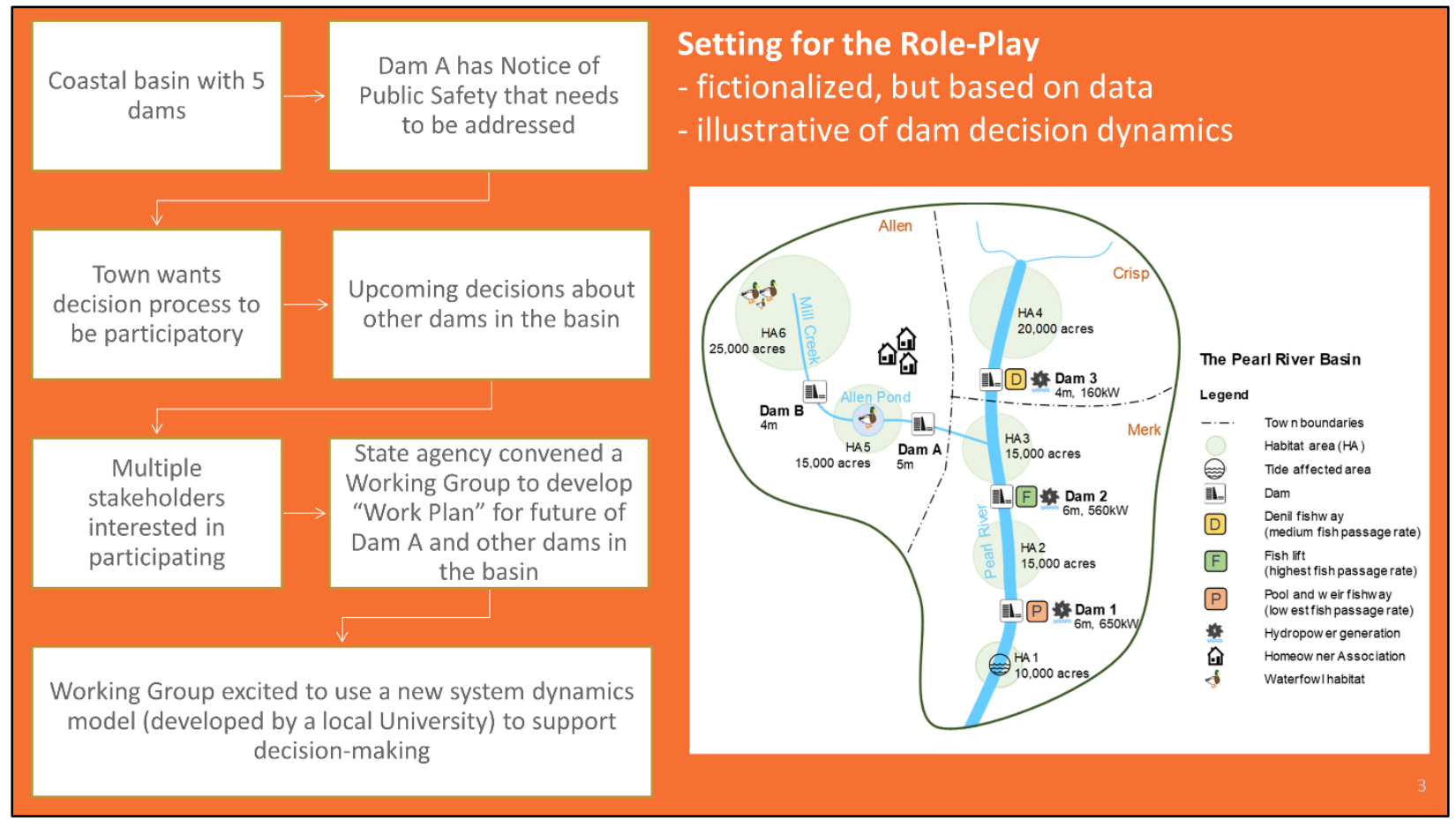

Character roles

based on actual

stakeholder types

\section{Who is attending today's meeting? Type of stakeholder}

Federal Agency of Natural Resources Federal government.

(FANR)

State Water Resources Division State government.

(WRD)

Historic Preservation Agency of the State government.

State (HPAS)

HydroEnergy, LLC. Hydropower developer and operator;

Dam owner.

Allen Pond Homeowner Association Property owners along Allen Pond.

Rivers-R-Us Non-governmental, non-profit

organization.

Town of Allen Municipal Official

Facilitation team to help run the

Municipal government; Dam owner.

meeting and assist the group in using

the system dynamics model 


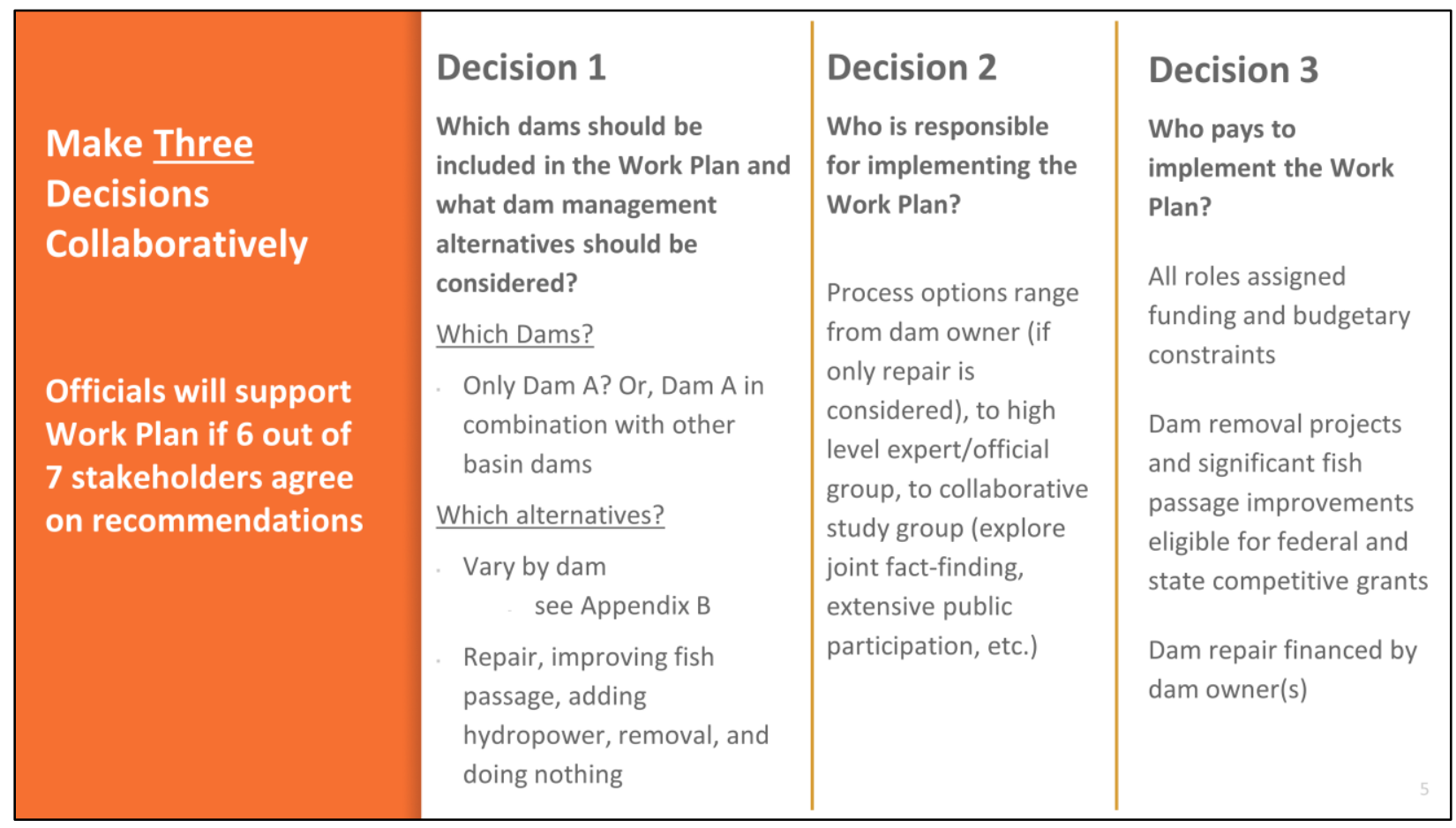






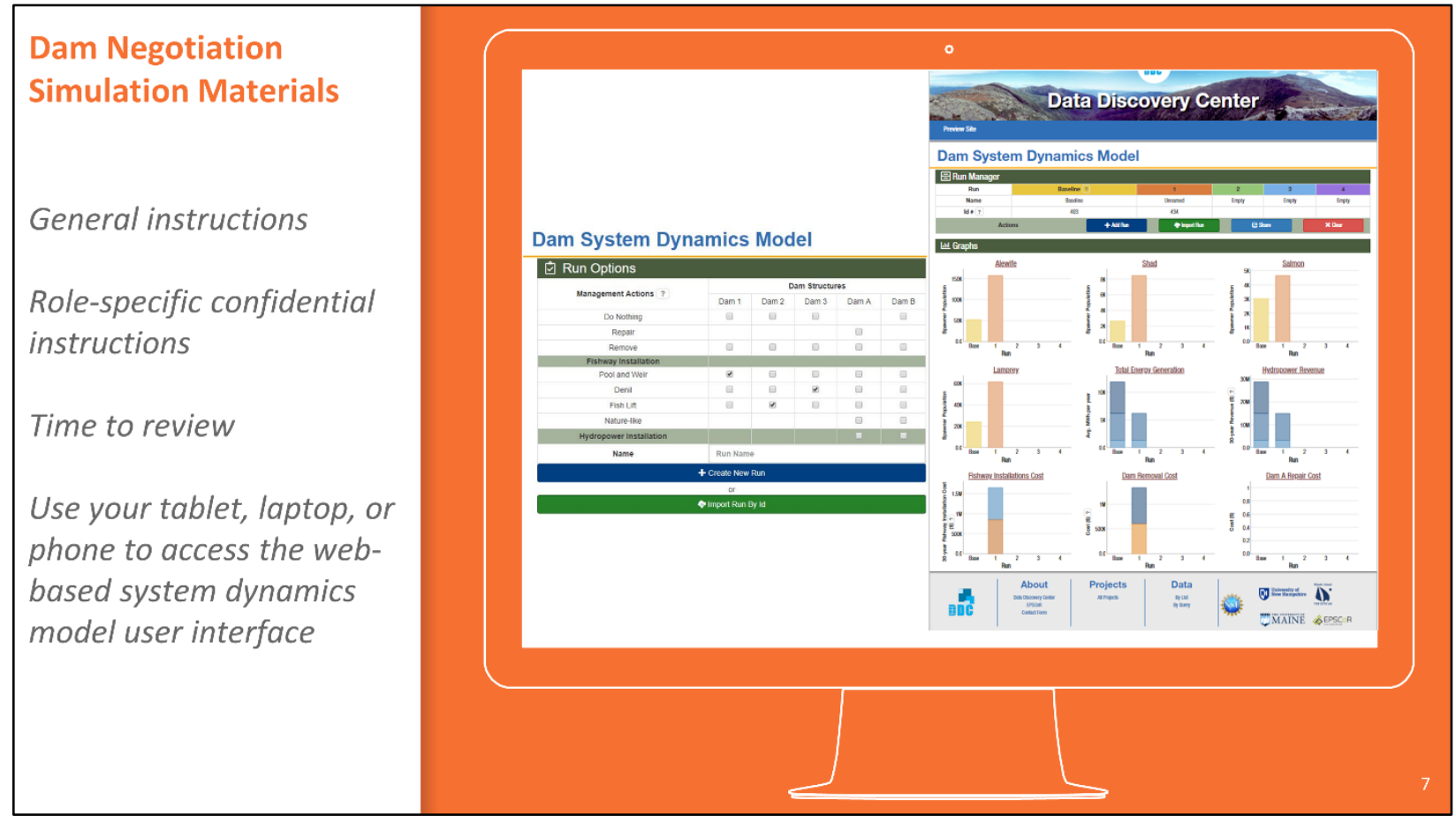

\section{System Dynamics Model Set-Up}

- Developed and validated for a real river (Song et al., 2018; Song and Mo, 2019)

- Daily calculations over 150 years

- Management options

- Dam removal

- Fishway installation

- Upgrade of nonpowered dams to hydroelectric ones

- Repair

- Key attributes

- Spawner population of four key fish species (alewife, American shad, Atlantic salmon, sea lamprey)

- Hydropower generation

- Economic cost (e.g., related to repair, fishway installation, removal)

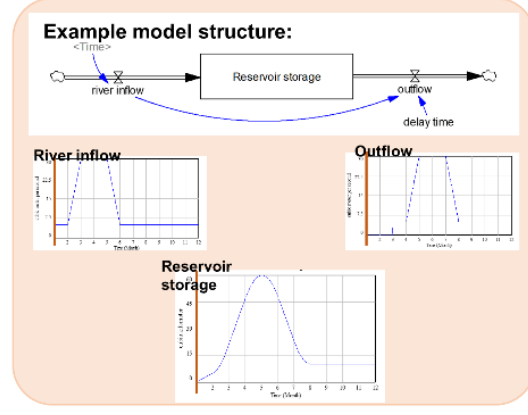




\section{Fish Population Model}

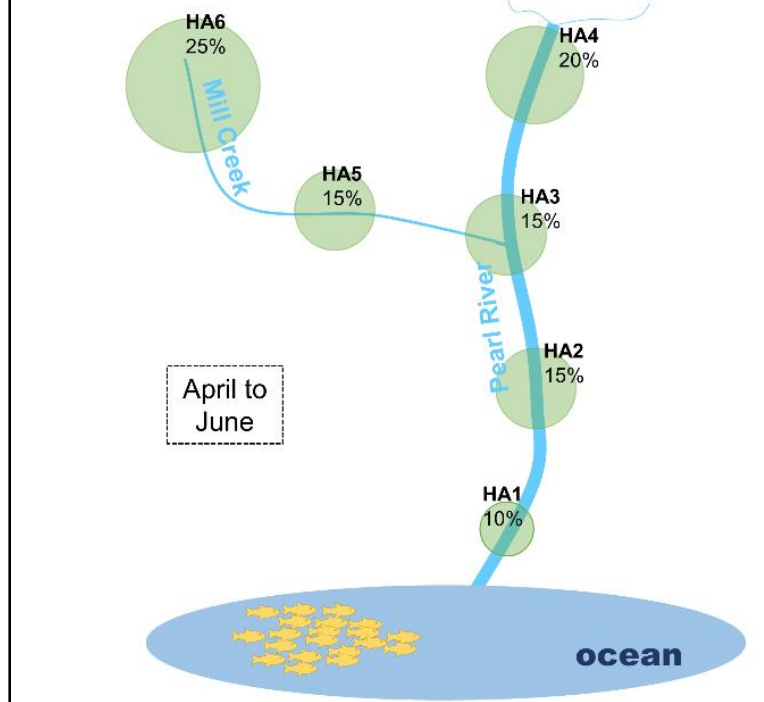

- Keep track of the activities and survival of different fish age groups throughout their entire life cycle

- Upstream migration: Dams block upstream migration

- Downstream migration: Turbine/dam kills

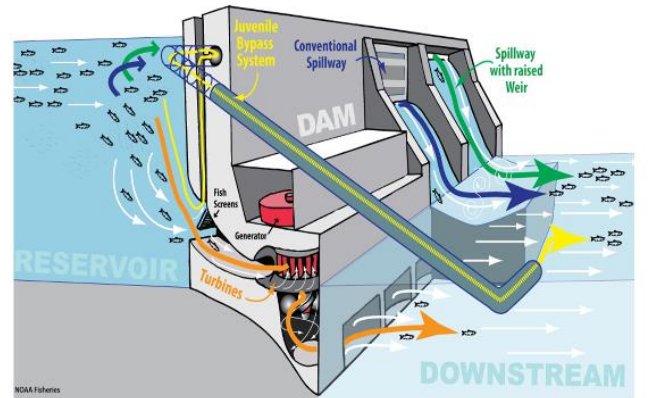

\section{Fish Population Model}

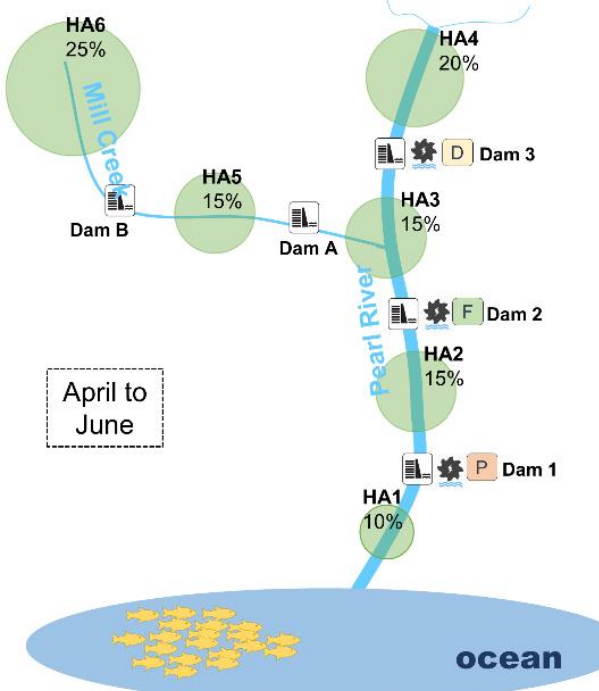

- Keep track of the activities and survival of different fish age groups throughout their entire life cycle

- Upstream migration: Dams block upstream migration

- Downstream migration: Turbine/dam kills

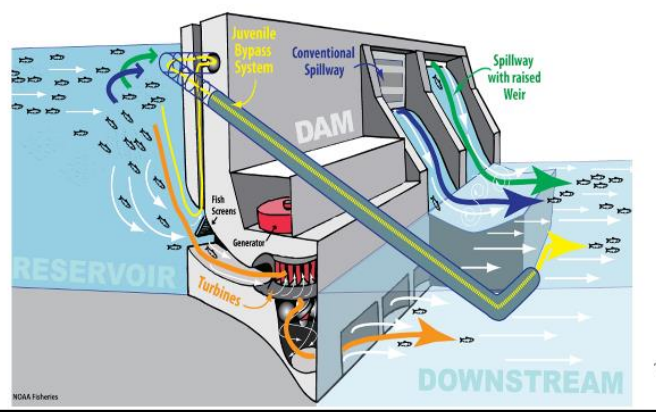




\section{Fish Population Model}
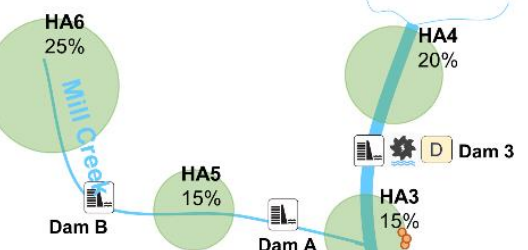

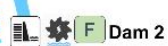

April to
June

June

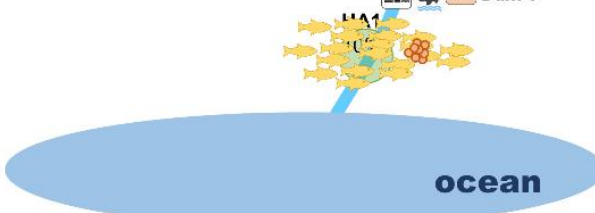

- Keep track of the activities and survival of different fish age groups throughout their entire life cycle

- Upstream migration: Dams block upstream migration

- Downstream migration: Turbine/dam kills

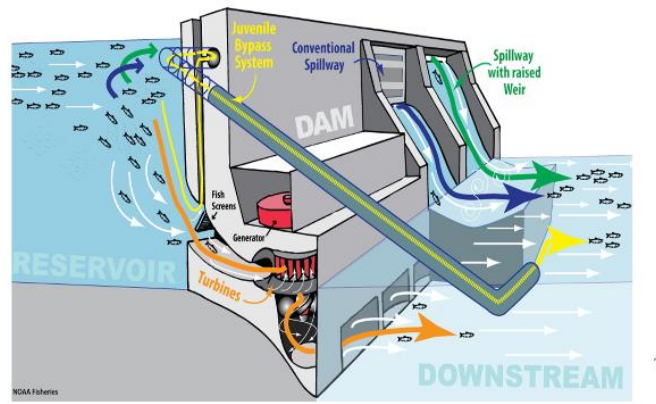

\section{Fish Population Model}

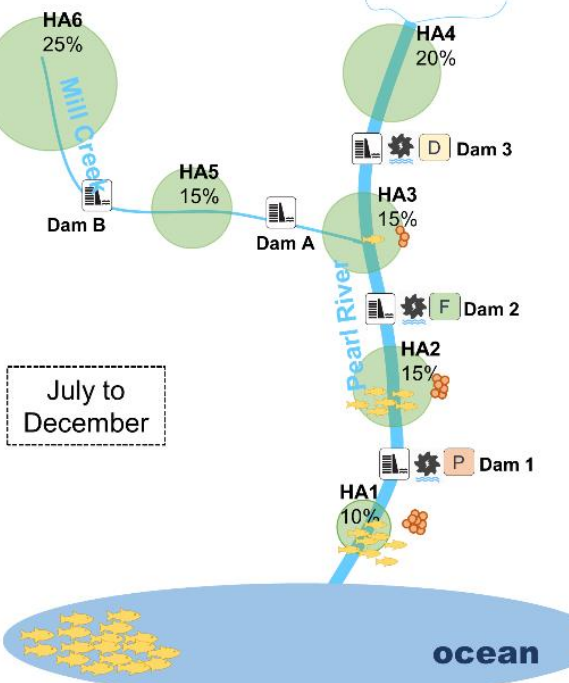

- Keep track of the activities and survival of different fish age groups throughout their entire life cycle

- Upstream migration: Dams block upstream migration

- Downstream migration: Turbine/dam kills

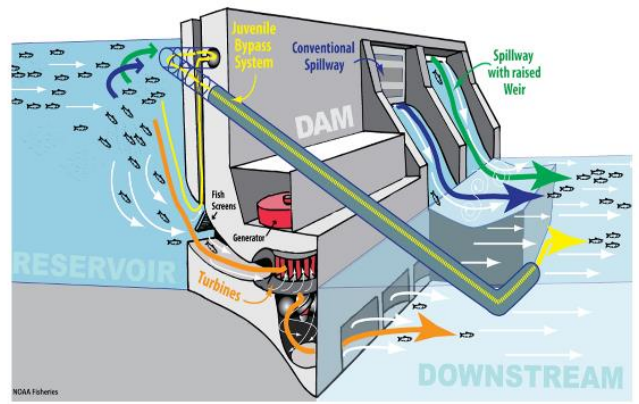




\section{Four Fish Species and Four Types of Fishways}

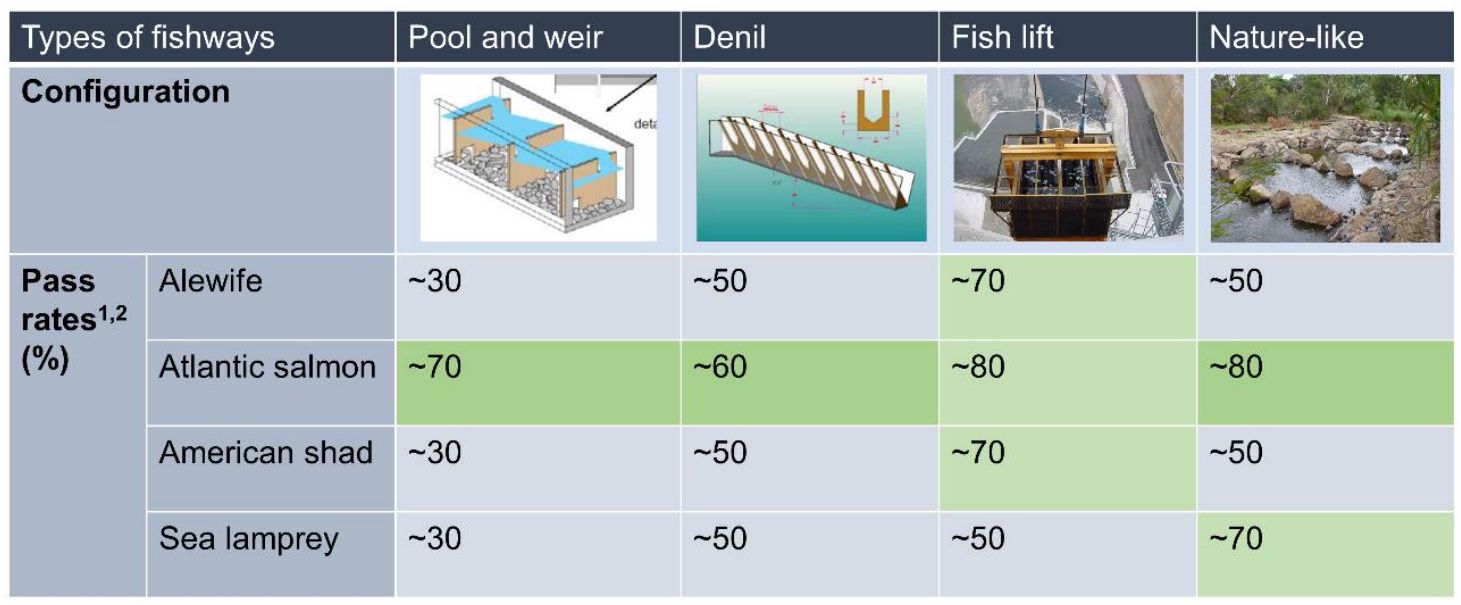

1. Noonan, M. J.; Grant, J. W. A.; Jackson, C. D., A quantitative assessment of fish passage efficiency. Fish and Fisheries 2012, 13, (4), 450-464.

2. Bunt, C. M.; Castro-Santos, T.; Haro, A., Performance of fish passage structures at upstream barriers to migration. River Research and Applications 2012, 28, (4), 457-478

\section{Energy Generation Model}

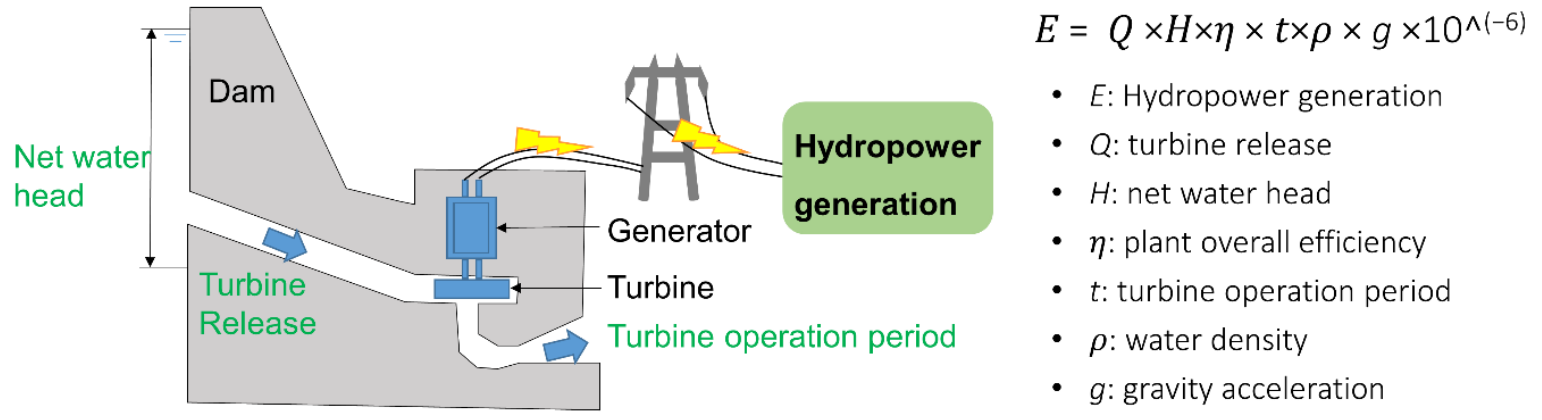

Energy-fish tradeoffs:

- Fishway installation: water diverted, slightly reduce hydropower generation

- Dam removal: Lost of the entire generation capacity

- Nonpowered dams can be upgraded to hydroelectric dams 


\section{Costs of Dam Removal and Fishway Installation}

- Calculated based upon dam height and the unit cost per vertical meter rise of the dam height

\begin{tabular}{|c|c|c|c|c|c|c|}
\hline \multirow[b]{2}{*}{ Technologies } & \multirow{2}{*}{$\begin{array}{l}\text { Unit cost per } \\
\text { vertical meter } \\
(\$ \text { million } / \mathbf{m})^{3,4}\end{array}$} & \multicolumn{5}{|c|}{ Capital cost (\$ million) } \\
\hline & & $\begin{array}{l}\text { Dam } 1 \\
(6 \mathrm{~m})\end{array}$ & $\begin{array}{l}\text { Dam } 2 \\
(6 \mathrm{~m})\end{array}$ & $\begin{array}{l}\text { Dam } 3 \\
(4 \mathrm{~m})\end{array}$ & $\begin{array}{l}\text { Dam A } \\
(5 \mathrm{~m})\end{array}$ & $\begin{array}{l}\text { Dam B } \\
(4 \mathrm{~m})\end{array}$ \\
\hline Pool and weir & 0.124 & 0.744 & 0.744 & 0.496 & 0.620 & 0.496 \\
\hline Denil & 0.133 & 0.798 & 0.798 & 0.532 & 0.665 & 0.532 \\
\hline Fish lift & 0.223 & 1.338 & 1.338 & 0.892 & 1.115 & 0.892 \\
\hline Nature-like & 0.120 & 0.720 & 0.720 & 0.480 & 0.600 & 0.480 \\
\hline Dam removal & 0.122 & 0.732 & 0.732 & 0.488 & 0.610 & 0.488 \\
\hline
\end{tabular}

3. Nieminen, E.; Hyytiäinen, K.; Lindroos, M., Economic and policy considerations regarding hydropower and migratory fish. Fish and Fisheries 2017, 18, (1), 54-78.

4. Turek, J.; Cavallaro, L.; Linder, C. Economic costs of diadromous fish passage in the Northeast; 2018

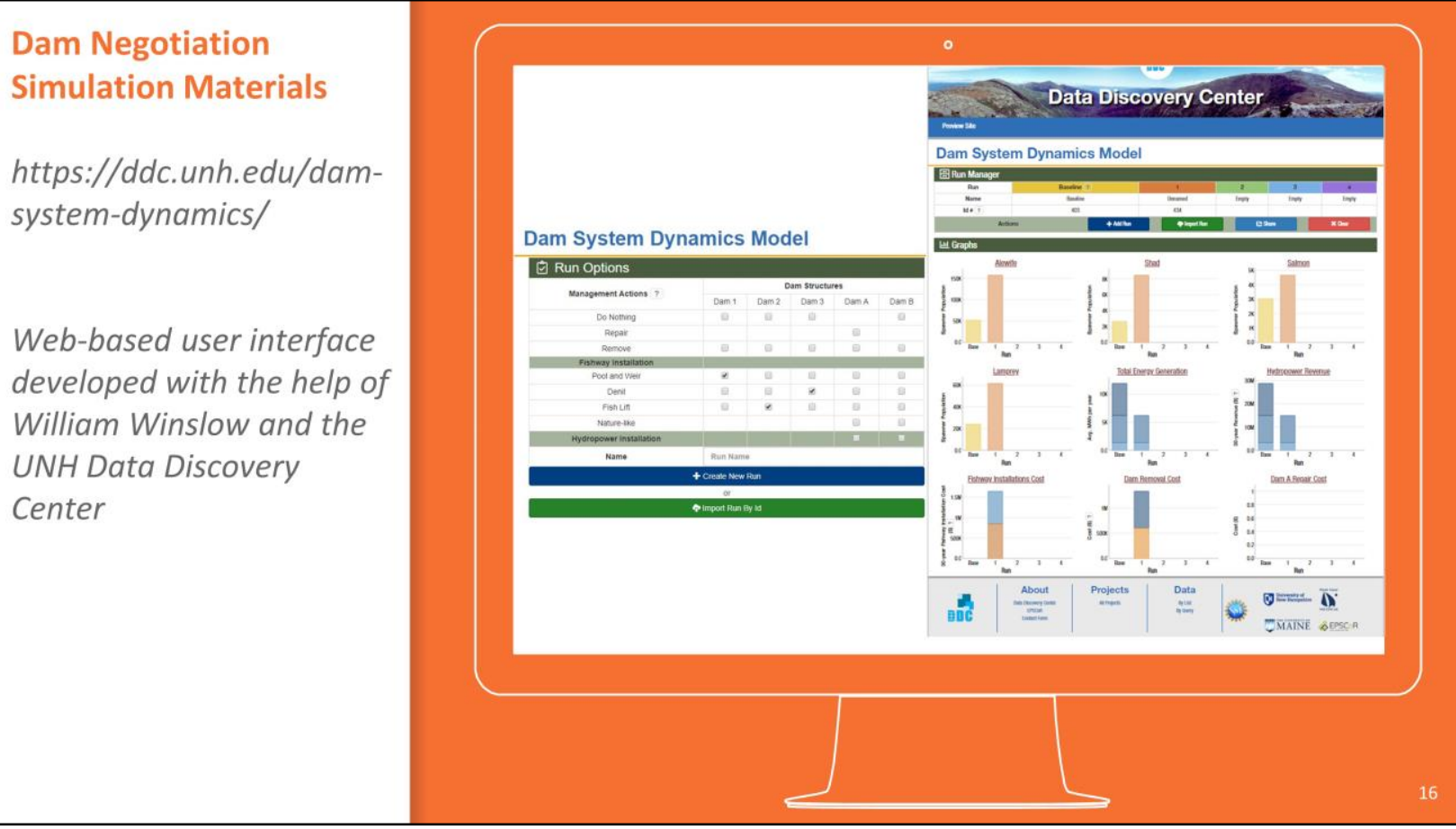




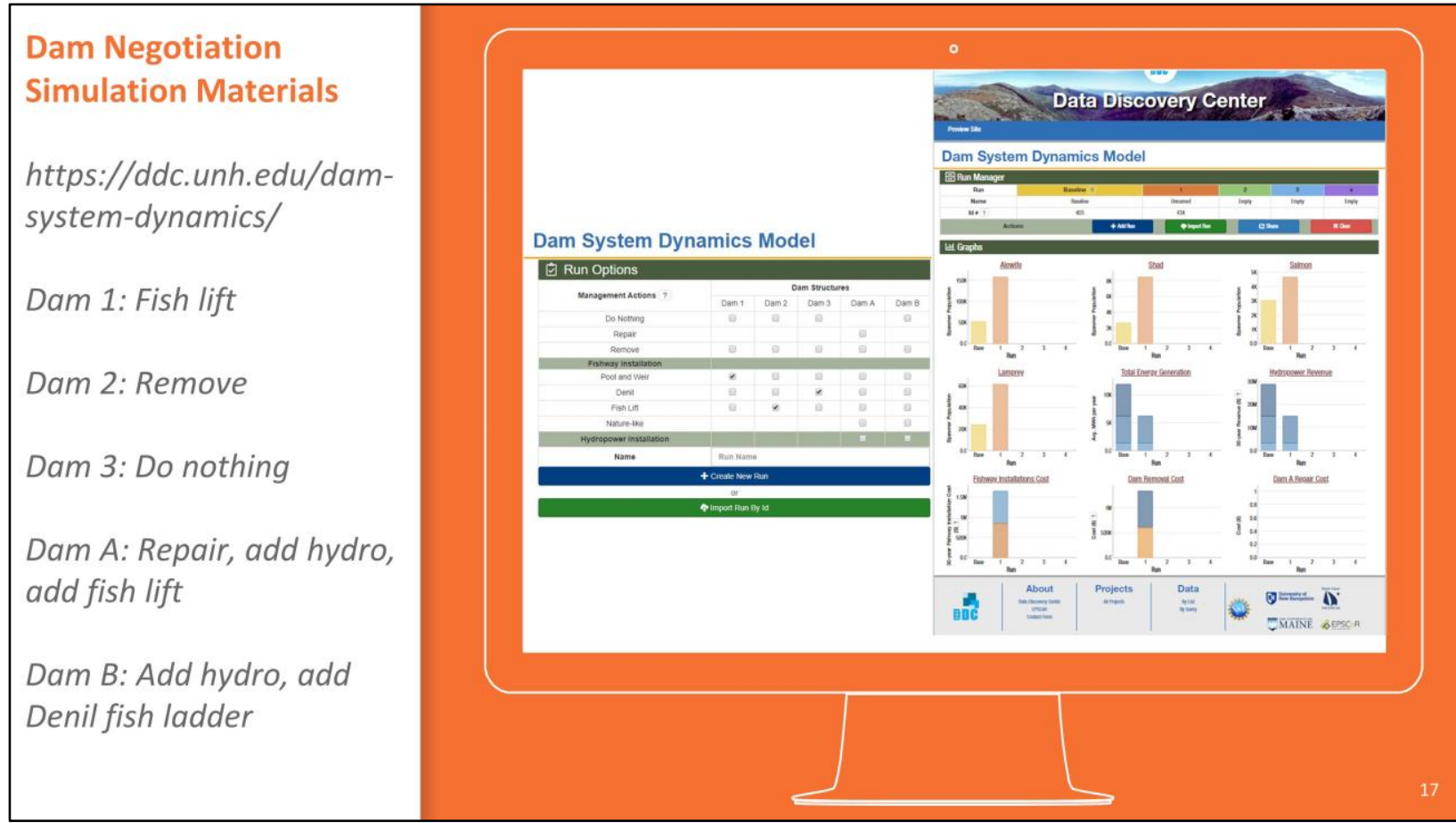

\section{Thank you!}
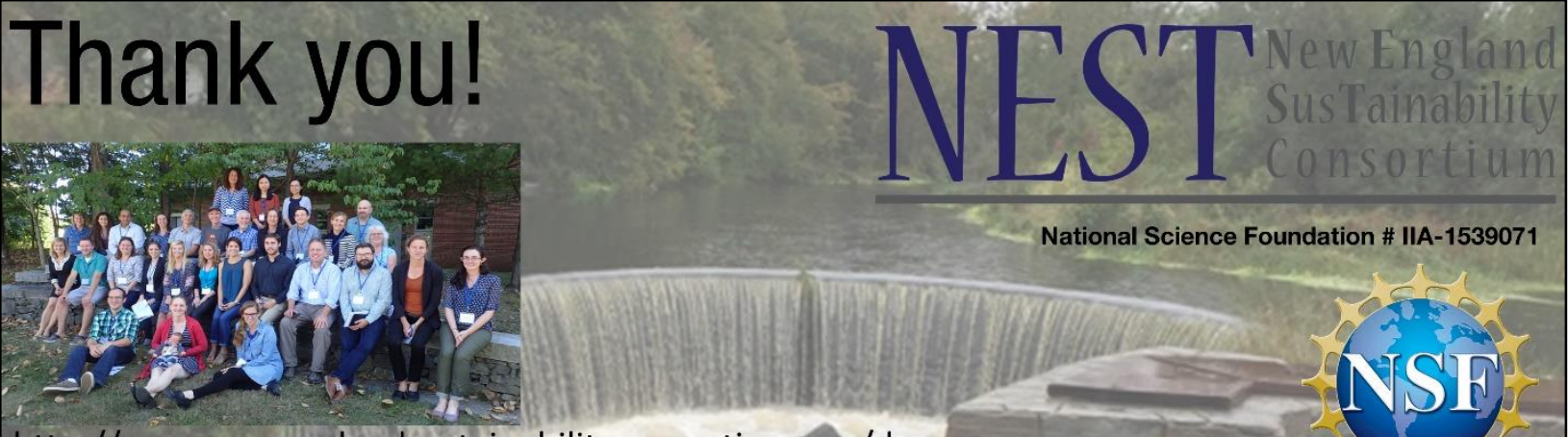

http://www.newenglandsustainabilityconsortium.org/dams
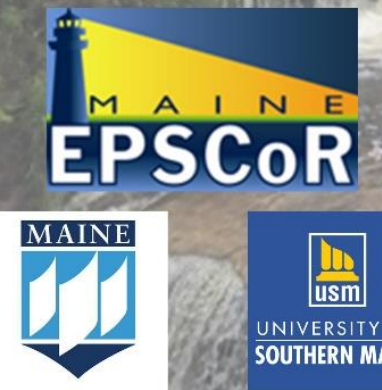

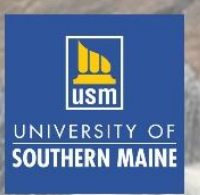

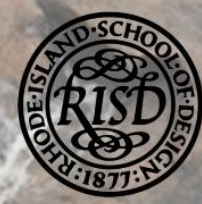

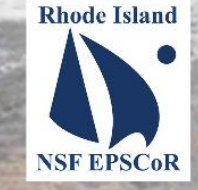

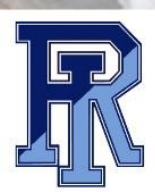

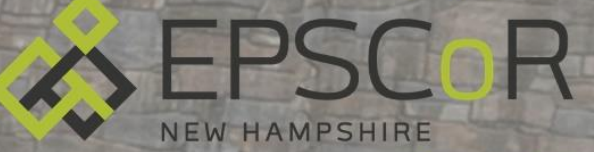

Keene STATE COLLEGE 


\section{Table Place Cards}

(next 7 pages) 

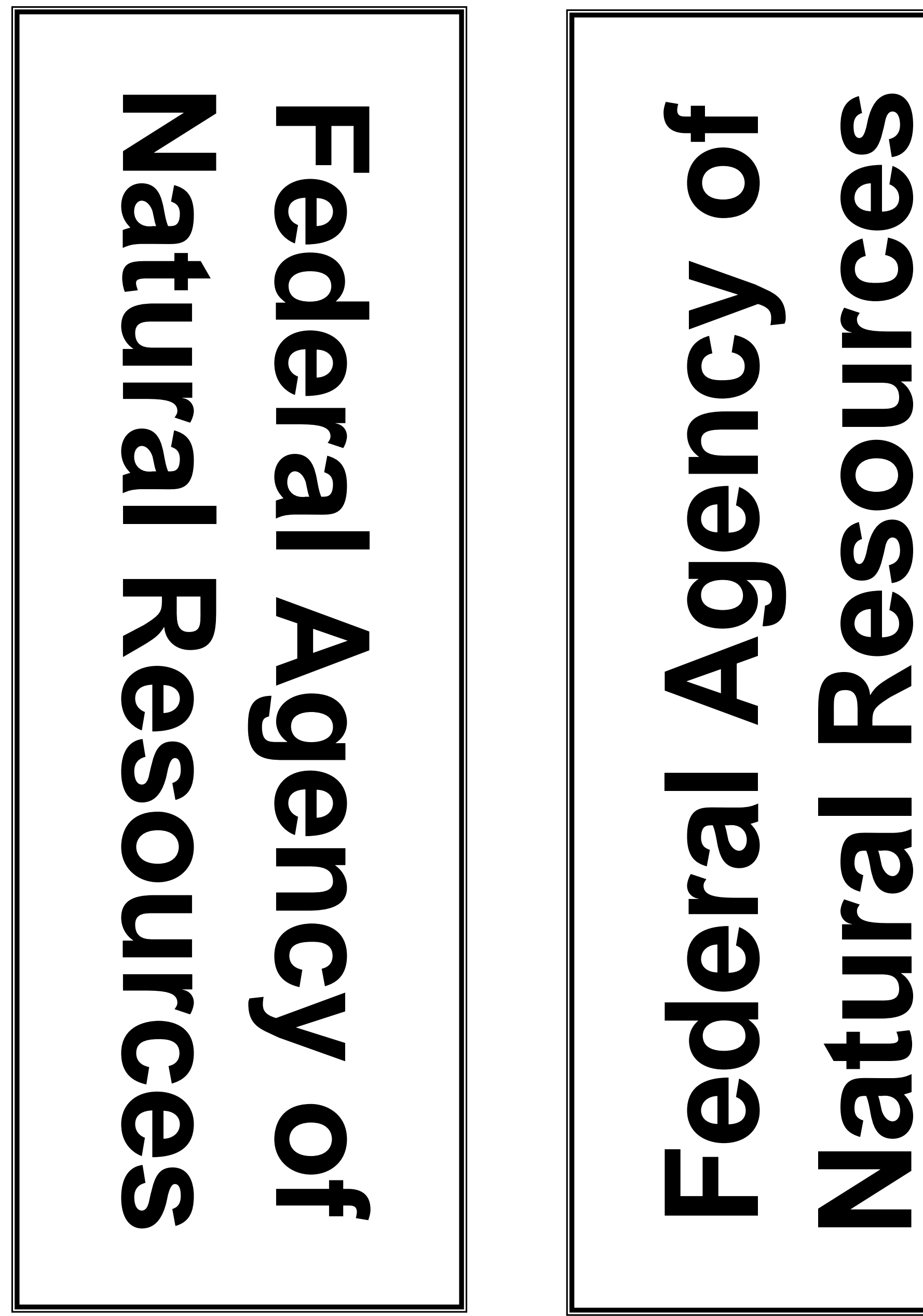

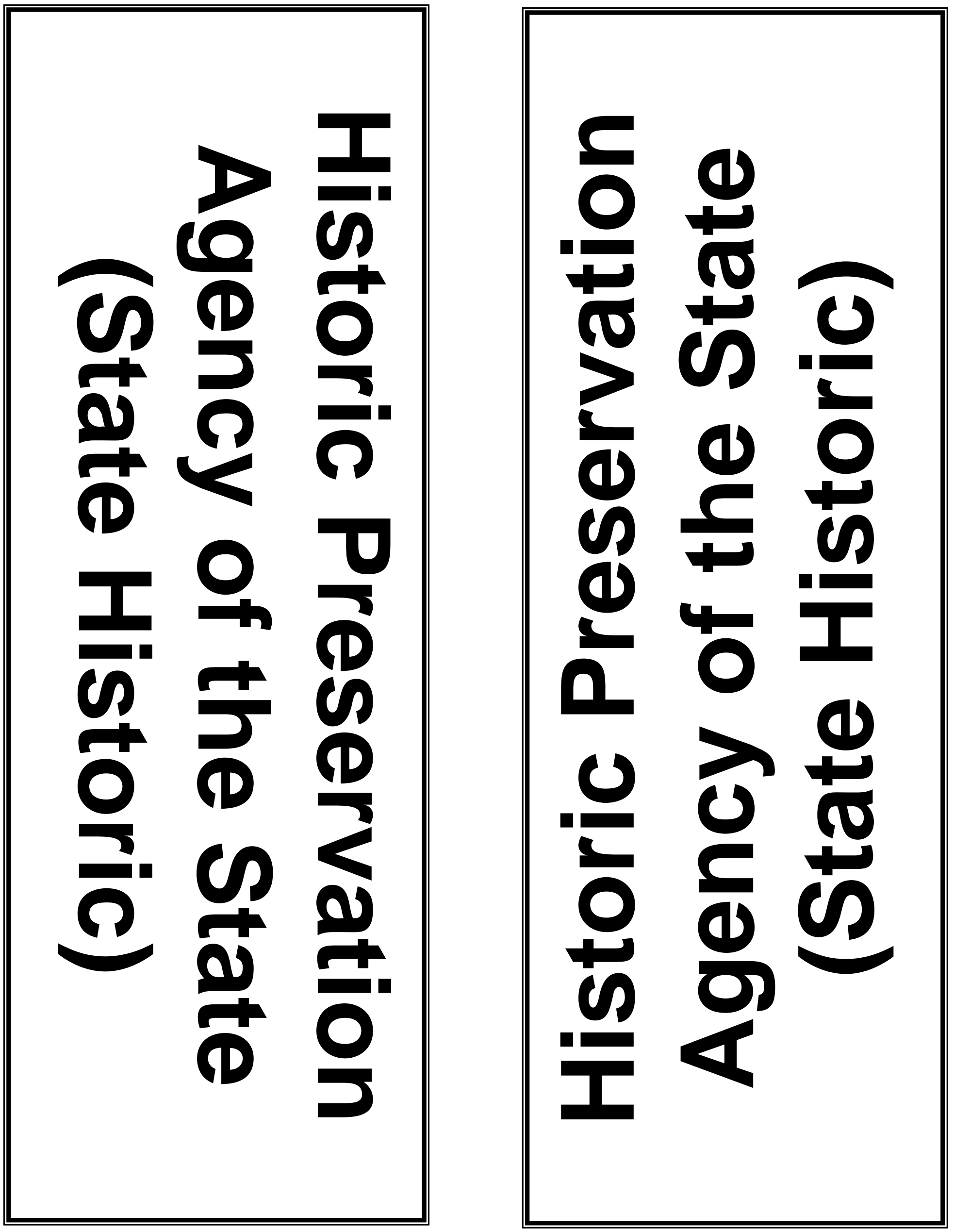

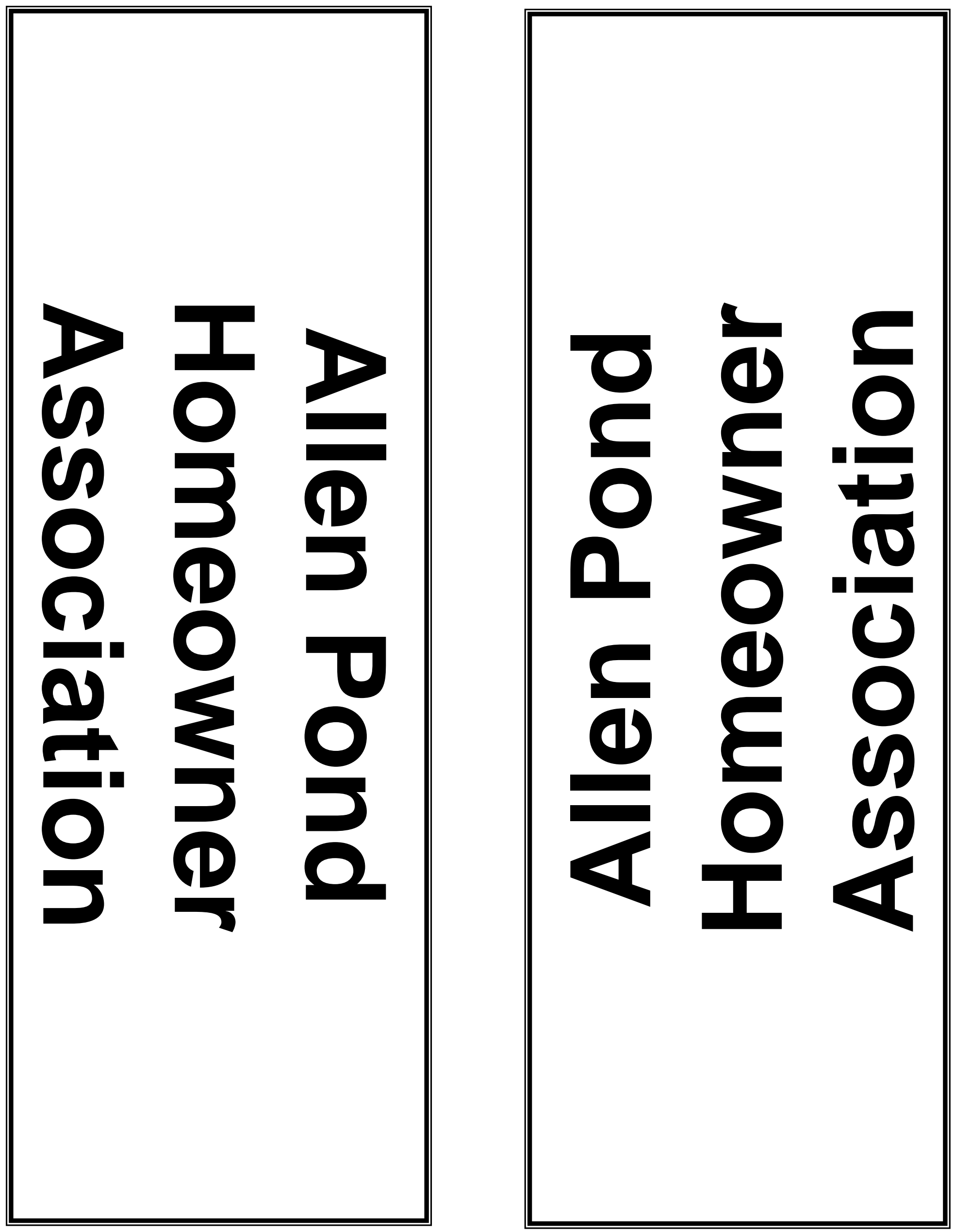

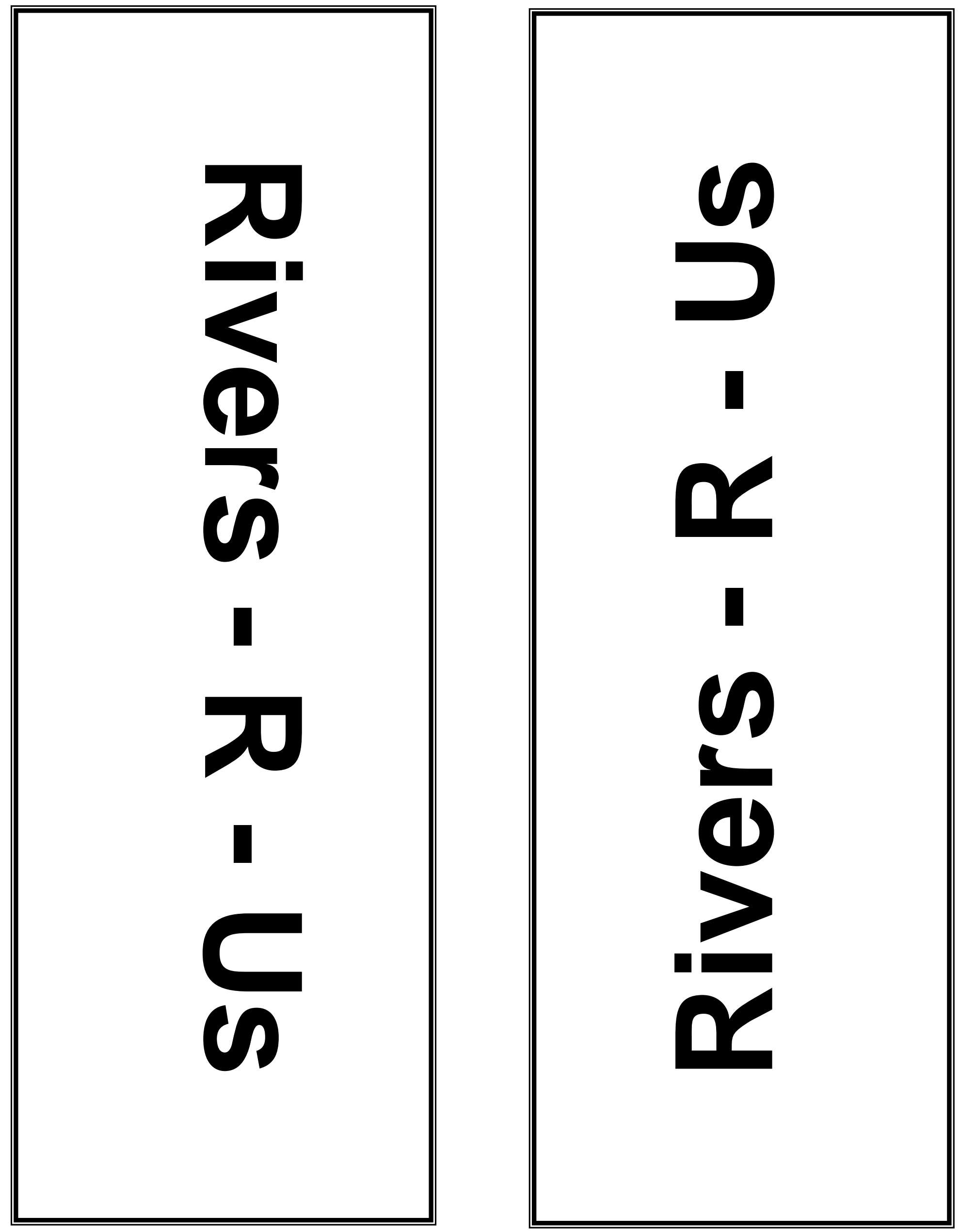

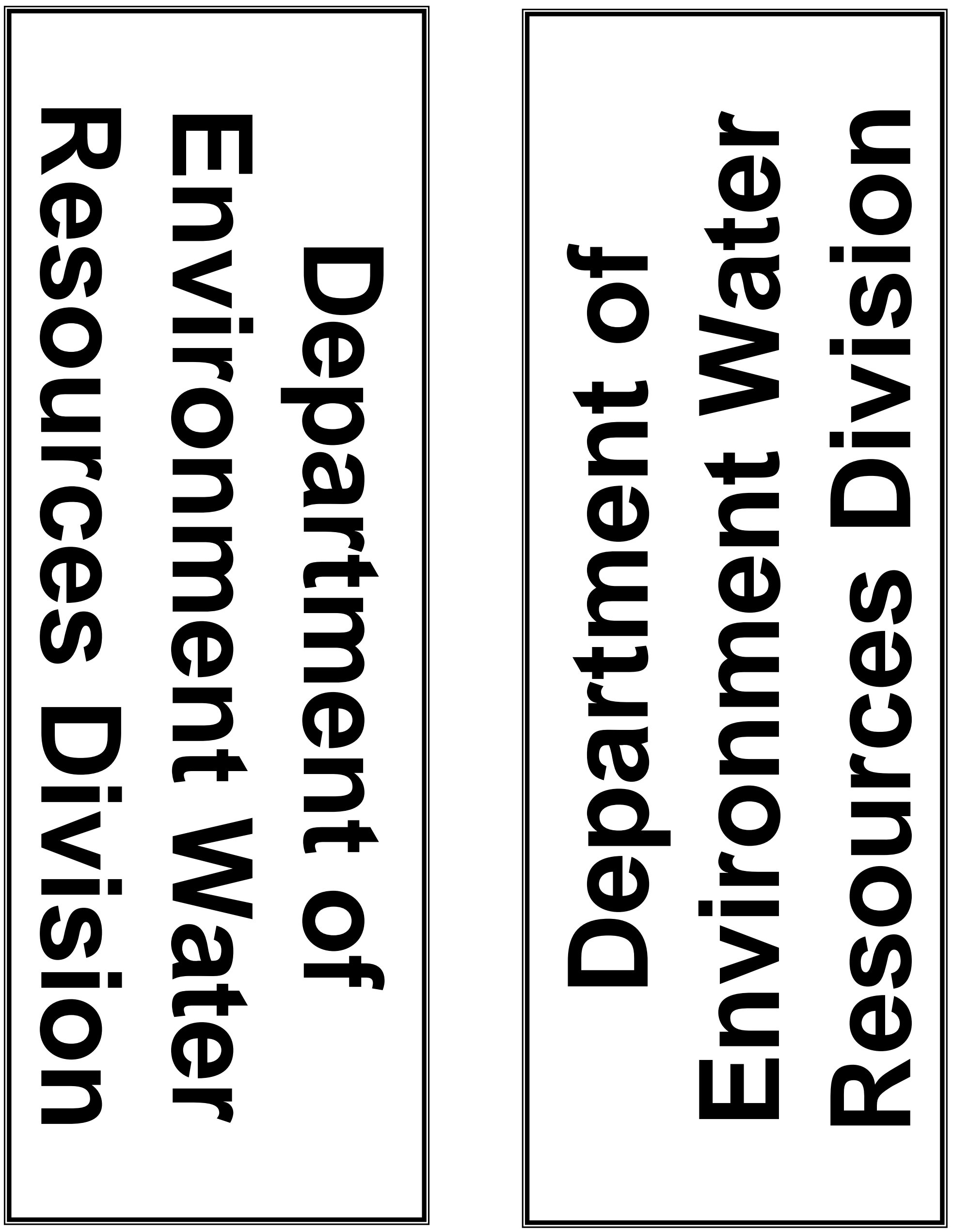

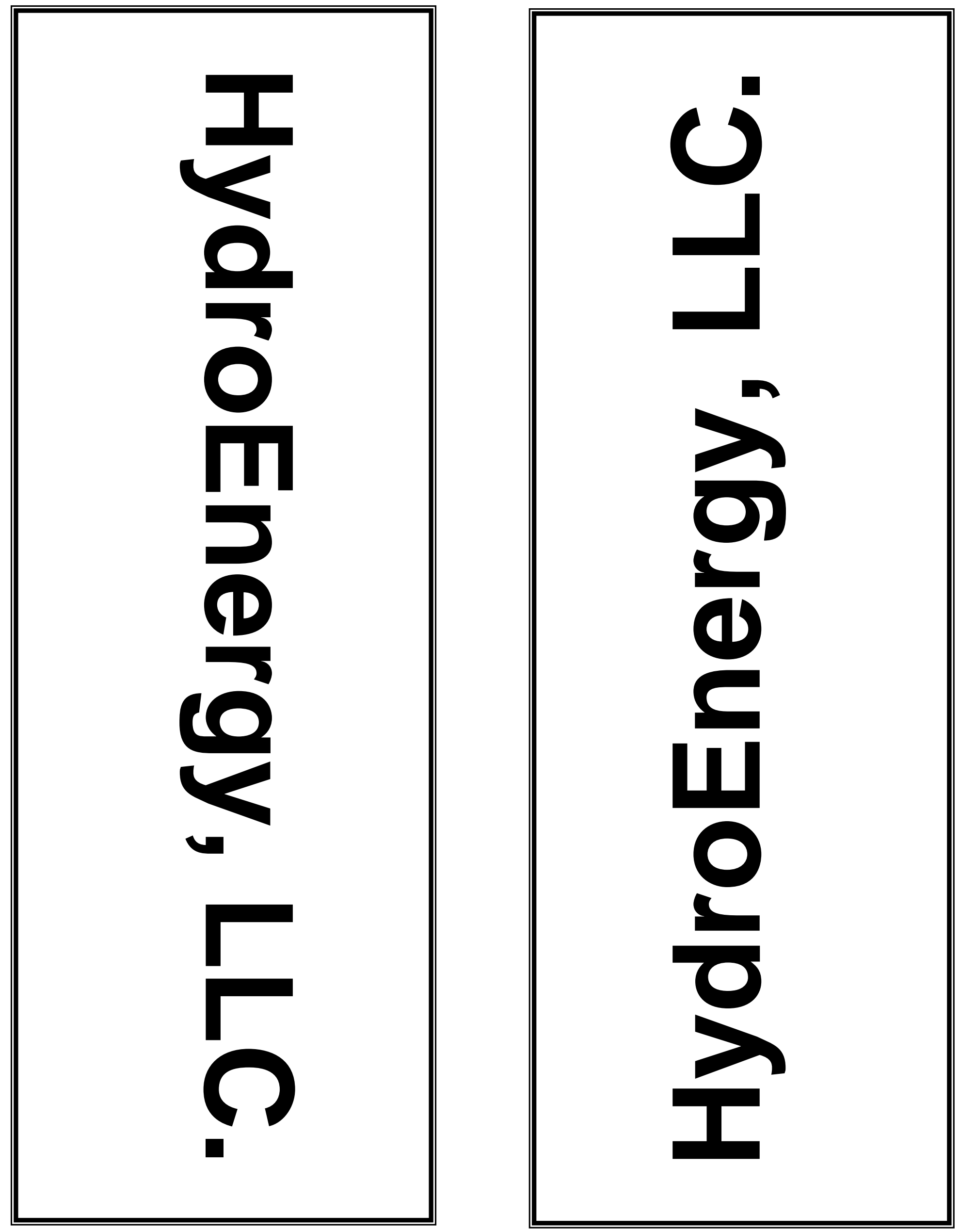

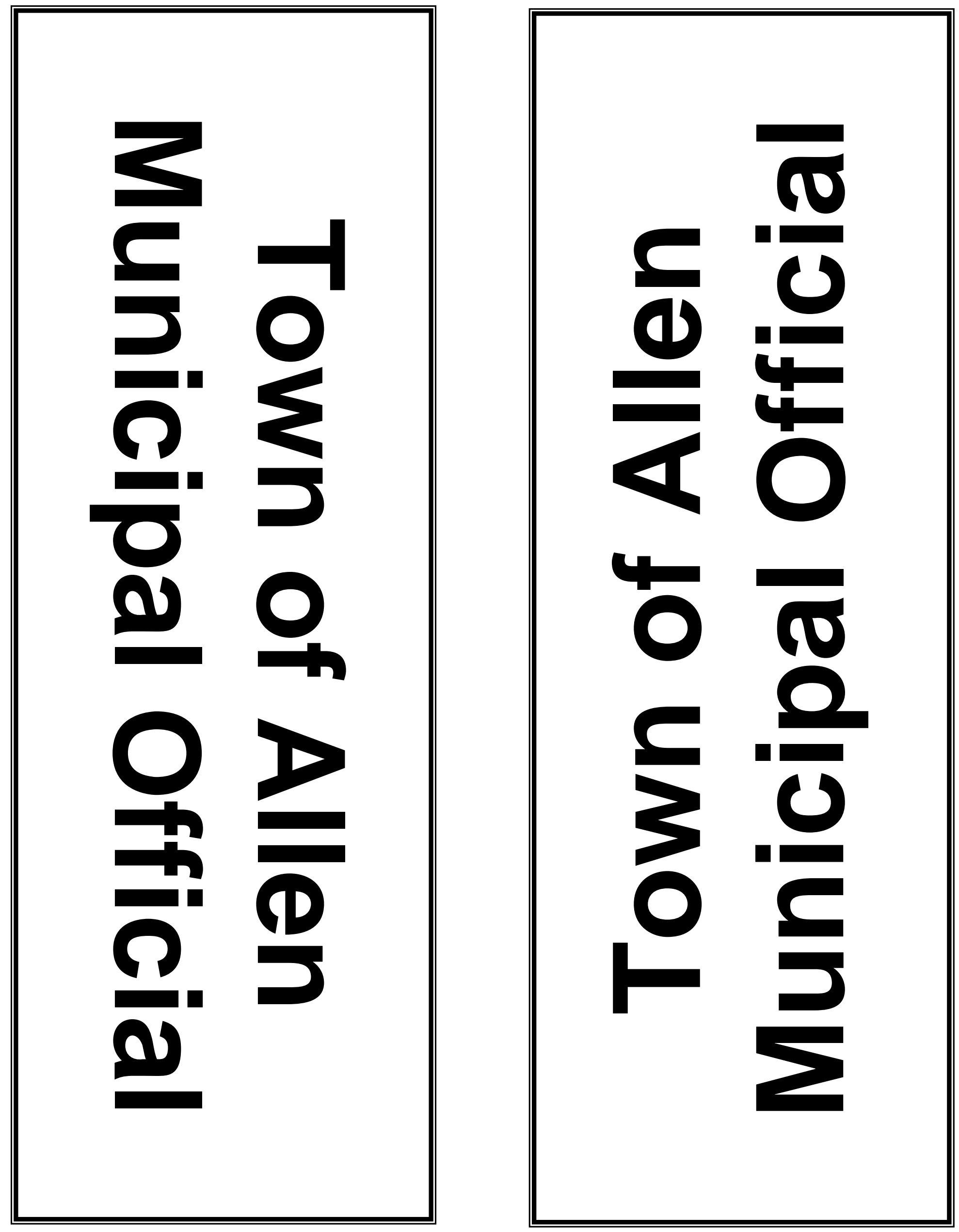


\title{
Pearl River Negotiation Simulation: Negotiating the Future of Dams
}

\author{
General Instructions for All Participants
}

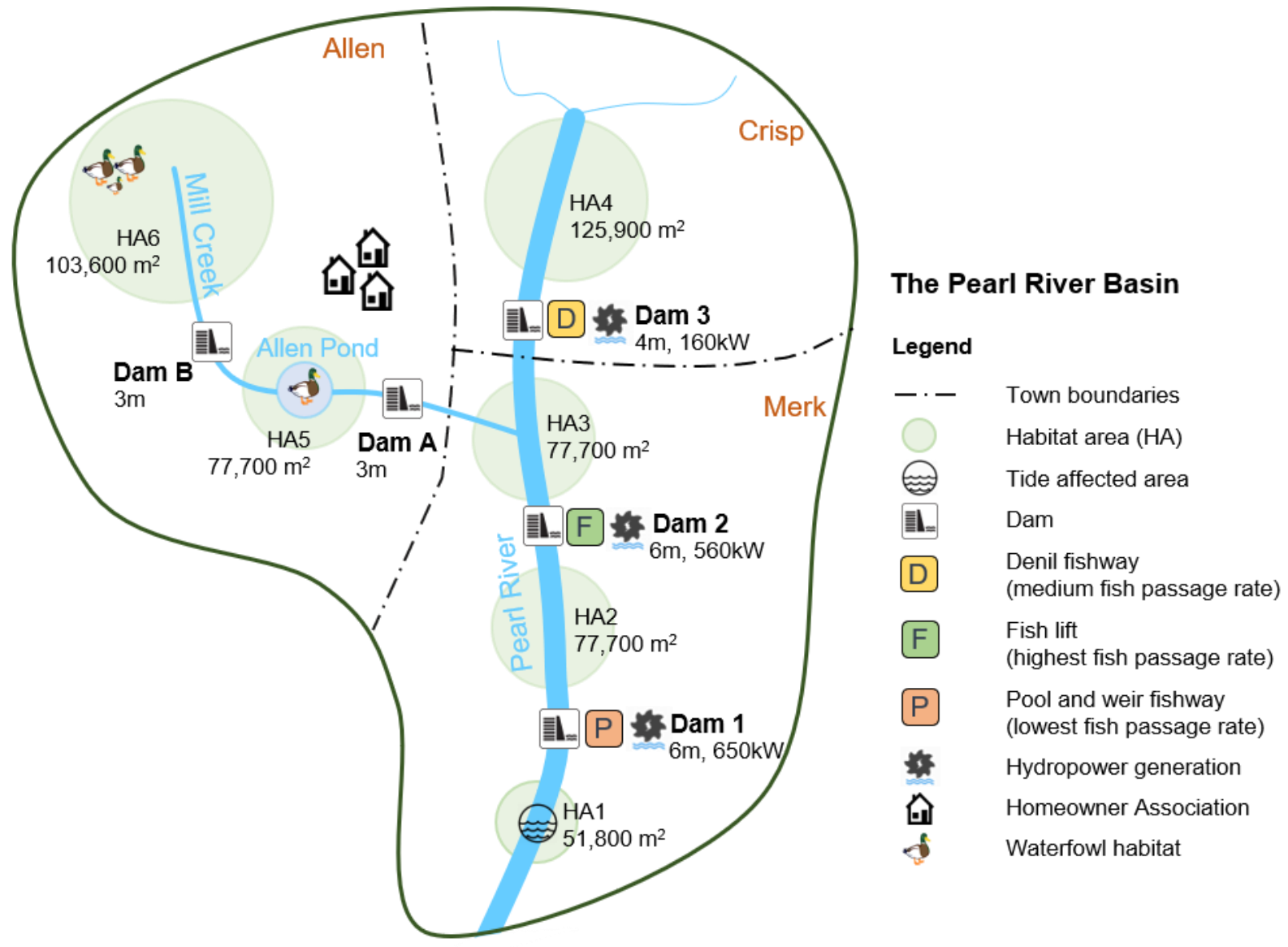

(C) 2020, University of New Hampshire, All rights reserved.

This case was written by Natallia Leuchanka Diessner, Dr. Catherine M. Ashcraft, Dr. Weiwei Mo, and Cuihong Song at the University of New Hampshire (UNH), Durham, NH, USA. William Winslow of the UNH Data Discovery Center helped with developing the web-based user interface. This case was developed with funding provided by the National Science Foundation's Research Infrastructure Improvement (NSF \#IIA-1539071). For further information, including licensing and permissions, please contact UNHInnovation at unh.innovation@unh.edu.

\section{Suggested citation:}

Diessner, Natallia Leuchanka, Catherine M. Ashcraft, Weiwei Mo, and Cuihong Song. 2020. "Pearl River Negotiation Simulation: Negotiating the Future of Dams." University of New Hampshire, Durham. https://dx.doi.org/10.34051/p/2020.394 


\section{INTRODUCTION}

The Town of Allen was recently notified that one of its dams on the Mill Creek (a tributary of the Pearl River) poses a threat to public safety. Originally built to power a former mill, the dam has not been maintained for decades and upgrades to meet safety regulations will require significant investment. The notice of deficiency has triggered controversy among Allen residents. Some think Dam A should be removed to restore the river. Others are concerned that removing Dam A will destroy Allen Pond, the impoundment behind the dam, decrease waterfront property values, and change Allen's cultural character as they know it. Complicating matters, the ecological benefits of removing Dam A are related to upcoming decisions about three hydropower dams on the mainstem of the Pearl River (Dams 1, 2, and 3).

In an effort to improve on previous contentious dam decisions, the State Water Resources Division (State WRD) convened a Working Group of interested parties to discuss opportunities for the Pearl River Basin dams with the goal of agreeing on a Work Plan. State WRD hopes this Working Group will foster broad stakeholder support and respond to concerns expressed by some stakeholders in the past that government officials were not adequately considering the general public interest in deciding how to spend public tax dollars. To support today's meeting, State WRD also invited a research team from a state university that recently developed a simulation tool for the Pearl River Basin, which can be accessed at https://ddc.unh.edu/damsystem-dynamics/. This tool simulates economic cost, populations of four different fish species (alewife, American shad, Atlantic salmon, and sea lamprey) that are of the highest economic and cultural value in the region, and hydropower generation under different dam management alternatives. The research team also shared renderings from a nearby basin to help visualize the effect of dam removal on the landscape (Appendix A). The Working Group has agreed to use these tools to support decisions about the dams, as well as to hire a neutral facilitation team to run today's meeting and provide technical assistance.

While the Working Group does not have final authority to make any decisions, the municipal, state, and federal officials have indicated they aim to act on the Work Plan if at least six out of the seven stakeholders support it (the State Water Resources Division has indicated it would prefer unanimous support of the Work Plan). If fewer than six stakeholders participating in the Working Group support the recommendations, the Town of Allen will decide on its own about next steps to respond to Dam A's notice of deficiency.

\section{THE PEARL RIVER BASIN DESCRIPTION}

The Pearl River Basin drains an area of approximately 200 square miles (128,000 acres). From its rural and sparsely developed headwaters, the Pearl River flows southeast until it becomes tidal below Dam 1. While the upper basin is largely forested, the lower basin is undergoing rapid population growth and urban development. The Pearl River Basin has a rich pre-industrial and industrial history. Archeological records show indigenous populations inhabited the basin for thousands of years and many Native American settlements were located next to the river falls where Europeans constructed dams to power the mills of the industrial revolution. Due to its unique ecological value, the Pearl River was recently designated a "State River of Significance", meaning that any development along its banks is carefully regulated by the State WRD. The 
River's mainstem is home to four fish species of significance: alewife, American shad, Atlantic salmon, and sea lamprey. Recent monitoring by the State Department of Fish, Wildlife, and Natural Resources indicated significant declines in sea-run fish populations and habitat quality, particularly as compared to historic levels.

There are five dams in the basin located across three municipalities (see basin map on cover). The current status and conditions of the five dams are outlined in Appendix $B$ and the river discharge at each dam is detailed in Appendix $C$. Dams 1,2, and 3 are owned and operated by a regional, medium-sized hydropower company, HydroEnergy, LLC. Hydropower generated from Dams 1, 2, and 3 is sold to surrounding municipalities, including Allen, Crisp, and Merk. Because of the hydropower generation, these municipalities enjoy a relatively low electricity rate. The three hydropower dams are nearing the process for renewing their operating licenses, which give permission and specify conditions to continue generating electricity using public waters. There are no known contaminated sediment issues behind any of the dams. None of the dams are used for flood control and, fortunately, none of the municipalities have been affected by major flooding events over the past five years.

Historically the primarily rural-residential Town of Allen (population: 15,000) has struggled economically. However, more recently, the Town is thriving due to new construction of a large shopping plaza and significant revenue from recreational opportunities provided by the 50 -acre Allen Pond (the impoundment created by Dam A). The pond-based recreational opportunities include birdwatching, migratory waterfowl hunting (mainly ducks and geese) by both resident and non-resident hunters, and fishing. The Town of Allen's median household income is $\$ 55,000$ and approximately $20 \%$ of Allen's residents hold a bachelor's degree. The Town of Crisp has a population of 10,000 residents and the City of Merk has approximately 30,000 residents.

\section{ABOUT TODAY'S MEETING}

\begin{tabular}{|l|l|}
\hline Who is attending today's meeting? & Type of stakeholder \\
\hline $\begin{array}{l}\text { Federal Agency of Natural Resources (Federal } \\
\text { ANR) }\end{array}$ & Federal government \\
\hline State Water Resources Division (State WRD) & State government \\
\hline $\begin{array}{l}\text { Historic Preservation Agency of the State } \\
\text { (State Historic) }\end{array}$ & State government \\
\hline HydroEnergy, LLC. & $\begin{array}{l}\text { Hydropower developer and operator; Dam } \\
\text { owner }\end{array}$ \\
\hline $\begin{array}{l}\text { Allen Pond Homeowner Association (Allen } \\
\text { HOA) }\end{array}$ & Property owners along Allen Pond \\
\hline Rivers-R-Us & Non-governmental, non-profit organization \\
\hline Town of Allen Municipal Official & Municipal government; Dam owner \\
\hline Facilitation Team & Neutral third-party; Not a stakeholder \\
\hline
\end{tabular}

The facilitation team met individually with the participants in advance of today's meeting to discuss their interests and concerns. Based on these meetings, the facilitators identified three decisions, described below, that should be part of the Work Plan, and options for each decision, 
intended to start today's discussion. The goal of today's meeting is to discuss and reach agreement on all three critical decisions. Of course, meeting participants are encouraged to be as creative as they can be within their constraints.

Decision 1: Which dams should be included in the Work Plan and what dam management alternatives should be considered?

- Option 1: Only Dam A

- Option 2: Dam A in combination with other dams in the basin

- Possible dam management alternatives vary by dam (see Appendix B and Appendix $C$ ).

\section{Decision 2: Who is responsible for implementing the Work Plan?}

- Option 1: High-Level Group. The owner(s) of the dam(s) included in the Work Plan (i.e. the Town of Allen and/or HydroEnergy, LLC.) will coordinate closely with federal and state officials to hold public hearings, select expert advisers and conduct studies, and make decisions.

- Option 2: Collaborative Study Group. A committee of interested residents from the Town of Allen will partner with municipal, state and federal government officials to jointly select expert advisers and conduct studies, will lead an extensive town-wide stakeholder process, for example through visioning forums and site visits, and will provide advice to the Town of Allen about studies and decisions about Dams A and B. HydroEnergy, LLC. will work closely with relevant stakeholders on decisions about Dams 1, 2, and 3.

- Option 3: Dam Owner(s). The owner(s) of the dam(s) included in the Work Plan (i.e. the Town of Allen and/or HydroEnergy, LLC.) lead implementation and coordinate with regulators when necessary.

\section{Decision 3: Who pays to implement the Work Plan?}

- Funding options depend on the details of the Work Plan. In general, dam removal projects and significant fish passage improvements are eligible for a combination of federal and state competitive grants to the dam owner(s). Dam repair projects are typically financed by the dam owner(s).

\section{Agenda for Today's Meeting}

- Facilitator opens the meeting and invites participants to make brief introductory statements about who they represent and their priority interests.

- 15 minutes of informal networking time (in-role). Participants are encouraged to have one-on-one or small group conversations and ask one another questions.

- Facilitated discussion about the three Work Plan decisions.

- Working break. Participants are encouraged to use this time to develop proposals for the Work Plan on their own or in small groups that address all three decisions.

- Brainstorming. Participants put forward Work Plan proposals.

- Deliberations. Participants discuss and evaluate Work Plan proposals, using the model. At 25 minutes and 10 minutes prior to the end of negotiations, the facilitator will call non-binding votes to assess group support for different proposals.

- Negotiations conclude at the end of the meeting. If no agreement is reached, the Town of Allen will decide on its own about next steps to respond to Dam A's notice of deficiency. 


\section{Appendix A: Rendering of Pre- and Post-Dam Removal in a Nearby Basin}
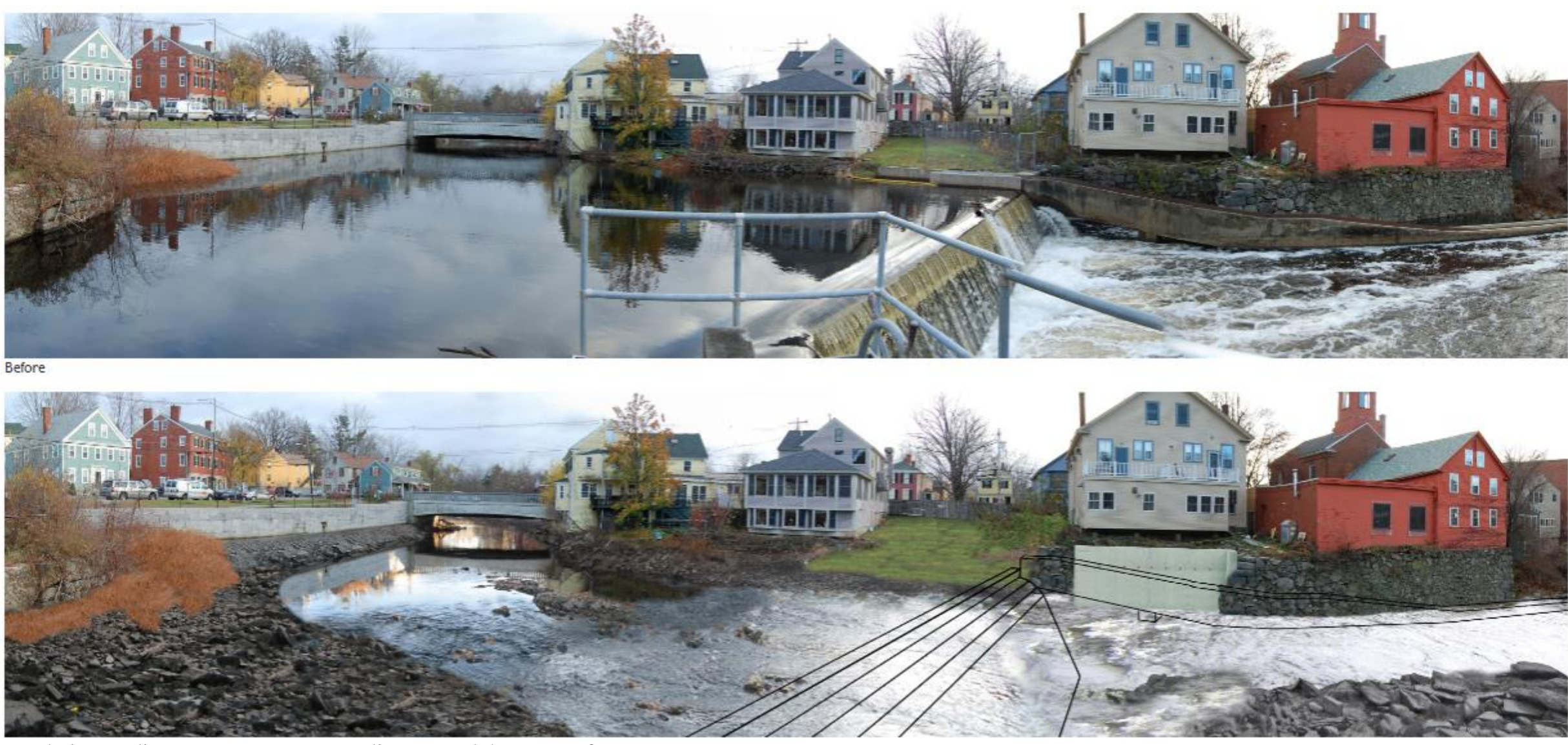

Rendering credit: Vanasse Hangen Brustlin, Inc. and the Town of Exeter, NH. 


\section{Appendix B: Descriptions of Pearl River Basin Dams}

\begin{tabular}{|c|c|c|c|c|c|c|}
\hline \multirow{2}{*}{$\begin{array}{l}\text { Dam } \\
1\end{array}$} & \multirow{2}{*}{$\begin{array}{l}\text { Owner } \\
\text { Hydro } \\
\text { Energy, } \\
\text { LLC. }\end{array}$} & \multirow{2}{*}{$\begin{array}{l}\text { River } \\
\text { Pearl } \\
\text { River }\end{array}$} & \multirow{2}{*}{$\begin{array}{l}\text { Municip } \\
\text { ality } \\
\text { City of } \\
\text { Merk }\end{array}$} & \multicolumn{2}{|c|}{ Current Status and Condition } & \multirow{2}{*}{$\begin{array}{l}\text { Management } \\
\text { alternatives } \\
\text { - } \quad \text { Do nothing } \\
\text { - } \\
\text { - } \quad \text { Impromove } \\
\text { passage }\end{array}$} \\
\hline & & & & $\begin{array}{l}\text { - Has relatively poor fish passage. } \\
\text { - To be relicensed, major improvements will be needed } \\
\text { to both fish passage and dam structure. }\end{array}$ & $\begin{array}{l}\text { - This dam is over } 50 \text { years old } \\
\text { - There are no Homeowner Associations around this } \\
\text { dam. }\end{array}$ & \\
\hline 2 & $\begin{array}{l}\text { Hydro } \\
\text { Energy, } \\
\text { LLC. }\end{array}$ & $\begin{array}{l}\text { Pearl } \\
\text { River }\end{array}$ & $\begin{array}{l}\text { City of } \\
\text { Merk }\end{array}$ & $\begin{array}{l}\text { - Has a high fish pass rate for all fish species. } \\
\text { - No major repairs expected to either fish passage or } \\
\text { dam structure for relicensing. }\end{array}$ & $\begin{array}{l}\text { - This dam is over } 50 \text { years old. } \\
\text { - There are no Homeowner Associations around this } \\
\text { dam. }\end{array}$ & $\begin{array}{l}\text { - } \quad \text { Do nothing } \\
\text { - } \quad \text { Remove }\end{array}$ \\
\hline 3 & $\begin{array}{l}\text { Hydro } \\
\text { Energy, } \\
\text { LLC. }\end{array}$ & $\begin{array}{l}\text { Pearl } \\
\text { River }\end{array}$ & $\begin{array}{c}\text { Town of } \\
\text { Crisp }\end{array}$ & $\begin{array}{l}\text { - Has medium quality fish passage. } \\
\text { It is uncertain whether fish passage repairs will be } \\
\text { needed for relicensing, but no structural repairs are } \\
\text { anticipated. }\end{array}$ & $\begin{array}{l}\text { - This dam is over } 50 \text { years old. } \\
\text { - There are no Homeowner Associations around this } \\
\text { dam. }\end{array}$ & $\begin{array}{l}\text { - } \\
\text { - } \text { Ro nothing } \\
\text { - Improve fish } \\
\quad \text { passage }\end{array}$ \\
\hline A & $\begin{array}{c}\text { Town of } \\
\text { Allen }\end{array}$ & $\begin{array}{c}\text { Mill } \\
\text { Creek }\end{array}$ & $\begin{array}{c}\text { Town of } \\
\text { Allen }\end{array}$ & $\begin{array}{l}\text { - Creates Allen Pond, an impoundment managed by the } \\
\text { Allen Pond Homeowner Association. The relatively } \\
\text { shallow Allen Pond provides high-quality habitat for } \\
\text { waterfowl and has no known water quality issues. } \\
\text { - No fish passage. } \\
\text { - Classified as a "High Risk" dam, meaning there would } \\
\text { be a loss of property and life if it were to fail. Recent } \\
\text { inspection determined the dam poses a threat to public } \\
\text { safety. } \\
\text { Preliminary studies suggest that it is unlikely that } \\
\text { removing Dam A would cause structural damage to } \\
\text { abutting infrastructure. }\end{array}$ & $\begin{array}{l}\text { - If Dam A is removed, the size of private property } \\
\text { lots will not change, as the restored floodplain } \\
\text { would become public land. } \\
\text { Qualifies for nomination to the National Register of } \\
\text { Historic Places. } \\
\text { - This dam is over } 50 \text { years old and its estimated date } \\
\text { of construction is believed to be in the early-mid } \\
1800 \text { s. The Town of Allen Heritage Commission } \\
\text { (TAHC) has evidence of both stone and concrete- } \\
\text { based material lining the walls near the dam, } \\
\text { although TAHC believes that about } 1 / 2 \text { of the wall is } \\
\text { over } 50 \text { years old. }\end{array}$ & $\begin{array}{ll}\text { - } & \text { Remove } \\
\text { - } & \text { Repair } \\
& \text { Repair \& Install } \\
\text { - } & \text { Repair \& Install } \\
& \text { fish passage \& } \\
\text { Install } \\
\text { hydropower }\end{array}$ \\
\hline B & $\begin{array}{c}\text { Town of } \\
\text { Allen }\end{array}$ & $\begin{array}{c}\text { Mill } \\
\text { Creek }\end{array}$ & $\begin{array}{c}\text { Town of } \\
\text { Allen }\end{array}$ & $\begin{array}{l}\text { - The relatively shallow, warm water impoundment } \\
\text { provides one of the highest-ranked habitats in the } \\
\text { region for waterfowl. } \\
\text { - Has no fish passage, but habitat above is considered to } \\
\text { be of relatively good quality and size for sea-run fish } \\
\text { spawning grounds. } \\
\text { - Has no public access and is not visible from surrounding } \\
\text { properties. }\end{array}$ & $\begin{array}{l}\text { - This dam is over } 50 \text { years old. } \\
\text { - There are no Homeowner Associations around this } \\
\text { dam. } \\
\text { Classified as a "Low Risk" dam, meaning there } \\
\text { would be no loss of life or significant damage to } \\
\text { property if it were to fail. }\end{array}$ & $\begin{array}{l}\text { - } \\
\text { - } \text { Remove nothing } \\
\text { - Install fish } \\
\text { passage } \\
\text { - Install fish } \\
\text { passage \& } \\
\text { Install } \\
\text { hydropower }\end{array}$ \\
\hline
\end{tabular}




\section{Appendix C: Fish Passage \& Discharge Data}

\begin{tabular}{|l|l|l|l|l|l|l|}
\hline & $\begin{array}{l}\text { Drainage area } \\
\text { at each dam } \\
\text { site }\left(\mathrm{km}^{2}\right)\end{array}$ & $\begin{array}{l}\text { Calculated } \\
\text { bankfull } \\
\text { width }(\mathrm{m})\end{array}$ & $\begin{array}{l}\text { Calculated } \\
\text { bankfull } \\
\text { mean } \\
\text { depth }(\mathrm{m})\end{array}$ & $\begin{array}{l}\text { Calculated } \\
\text { cross- } \\
\text { section } \\
\text { area }\left(\mathrm{m}^{2}\right)\end{array}$ & $\begin{array}{l}\text { Calculated } \\
\text { bankfull } \\
\text { discharge } \\
\left(\mathrm{m}^{3} / \mathrm{s}\right)\end{array}$ & $\begin{array}{l}\text { Calculated } \\
\text { bankfull } \\
\text { discharge } \\
\left(\mathrm{m}^{3} / \mathrm{d}\right)\end{array}$ \\
\hline Dam 1 & 466 & 37 & 1.3 & 50 & 67 & $5,789,000$ \\
\hline Dam 2 & 389 & 35 & 1.3 & 44 & 58 & $5,011,000$ \\
\hline Dam 3 & 130 & 22 & 0.9 & 20 & 24 & $2,074,000$ \\
\hline Dam A & 181 & 26 & 1 & 26 & 31 & $2,678,000$ \\
\hline Dam B & 104 & 20 & 0.9 & 18 & 20 & $1,728,000$ \\
\hline
\end{tabular}

Table 1: Baseline stream data (in standard metric units).

Table 2: Fishway passage rates for different types of fish species.

\begin{tabular}{|l|l|l|l|l|}
\hline \multirow{2}{*}{ Fish species } & \multicolumn{4}{|c|}{ Fish passage rates (\%) } \\
\cline { 2 - 5 } & $\begin{array}{l}\text { Pool and } \\
\text { weir }\end{array}$ & Denil & Fish lift & $\begin{array}{l}\text { Nature- } \\
\text { like }\end{array}$ \\
\hline Alewife & $\sim 30$ & $\sim 50$ & $\sim 70$ & $\sim 50$ \\
\hline Atlantic salmon & $\sim 70$ & $\sim 60$ & $\sim 80$ & $\sim 80$ \\
\hline American shad & $\sim 30$ & $\sim 50$ & $\sim 70$ & $\sim 50$ \\
\hline Sea lamprey & $\sim 30$ & $\sim 50$ & $\sim 50$ & $\sim 70$ \\
\hline
\end{tabular}




\section{Appendix D: Frequently Asked Questions}

How will decisions be made within today's negotiation?

Participants should strive to agree on a Work Plan that everyone can live with. However, if consensus cannot be reached, then a six-out-of-seven vote is needed on the Work Plan. The owner of any dam included in the Work Plan must be part of the agreement and any participant contributing funding must be part of the agreement.

What is the best outcome possible?

Multiple creative outcomes are possible. The best agreements respond to the participants' priorities and interests.

What happens if the participants do not reach agreement?

If fewer than six stakeholders participating in the Working Group support the Work Plan, the Town of Allen will decide on its own about next steps to respond to Dam A's notice of deficiency. Opponents may seek to challenge any such decision.

How much information should I share during the negotiation?

While participants are not allowed to show their Confidential Instructions to one another, each negotiator should share (or not share) whatever information and be as truthful (or untruthful) as they think appropriate.

How closely do I have to follow the Instructions?

Participants must negotiate within the confidential constraints of their role, even if their interests and beliefs in life are different. However, participants are also encouraged to be as creative as possible! The group may invent decisions or other options as long as they are consistent with the information in the General and Confidential Instructions.

Are side meetings allowed?

Participants are not required to negotiate as a full group the entire time. However, in the interest of time, side meetings should be kept brief. If multiple groups are negotiating in parallel at the same time, each group should operate independently of one another. 


\section{Pearl River Negotiation Simulation: Negotiating the Future of Dams Confidential Instructions \& Process Agenda for the Lead Facilitator}

You're very pleased to have been selected to facilitate today's Working Group discussions. As a reminder you have extensive experience working with governments, non-governmental organizations, communities and businesses to negotiate effectively, build consensus and resolve disputes. In advance of today's meeting, you conducted preliminary interviews with a broad range of stakeholders and feel confident today's meeting includes the right people for the upcoming dam-related negotiations. All participants have agreed to your selection as facilitator. This memorandum provides a briefing from your staff to assist in today's meeting.

\section{$\underline{\text { Negotiation Agenda }}$}

Negotiation (2 hours and 30 minutes)

- (10 min) Introductions and ground rules

Introduce yourself. This is a good opportunity to remind the participants they selected you to help manage today's meeting. You have no prior relationships with any of the participants in today's meeting and you do not have a stake in any particular outcome. You can ask participants that should they have any concerns about your impartiality, to please raise them with you directly so you can try to address them. Remind the participants they are the experts in the room regarding the Pearl River Basin and should draw on the expertise of their role and what they learn about one another's interests and the model to guide their decision-making. As a facilitator, you are here to help guide the discussion and help the participants stay on time.

Introduce a draft agenda for today (included in their materials) and the ground rules (you may want to write these out on a flip chart ahead of time):

- Be respectful of one another - no personal attacks or disparaging comments

$\circ$ Give others opportunity to speak - make points succinctly and don't speak over one another or interrupt

- Negotiate in good faith by sharing your interests and making an effort to understand one another's

○ Look for mutually beneficial outcome: Everyone's entitled to pursue their personal/organization's interests, but will also seek to take into account the interests of the whole group

$\circ$ If you disagree with a proposal - you accept responsibility to offer an alternative to accommodate own interests and those of others

$\circ$ Keep caucus meetings brief

$\circ$ Ask if participants want to add anything to this list.

Invite each participant to make a statement of NO MORE THAN 30 seconds introducing their role and priority interests. 
- (15 min) Networking and/or model exploration time.

Invite the participants to spend the next 15 minutes meeting one-on-one or in small subgroups to learn about one another's interests. In this part of the negotiation you do not have any specific responsibilities, as the negotiators are not meeting as a group. Prompt participants to take advantage of the time to meet individually with as many of the parties as you can to better understand their interests and priorities. If possible, you may facilitate open discussions among the participants of their priority concerns, to help each participant come to a better understanding of one another's interests.

- (40 min) Negotiation continues; Facilitated discussion of each of the three decisions Spending about 10 minutes on each decision, ask the participants to discuss each of the three decisions. It is very possible different stakeholders understand the issues differently, so your challenge is to ask questions to clarify what the decisions mean to the participants. It is not your job to define the decisions for the participants- draw on their expertise. If participants make statements about preferred outcomes, you can follow up with questions asking them to explain "Why" they want what they want. Make sure everyone has an opportunity to speak. During the conversation you may want to record the parties' interests on a stakeholder table (flip chart).

For example (you can modify this however you see fit, depending on whether you have access to a flip chart or a dry erase board (which has more space)):

\begin{tabular}{|l|l|l|l|}
\hline Role & Decision 1 (D1) & Decision 2 (D2) & Decision 3 (D3) \\
\hline Federal ANR & $\begin{array}{l}\text { Interest 1 for D1 } \\
\text { Interest 2 for D1 }\end{array}$ & $\begin{array}{l}\text { Interest 1 for D2 } \\
\text { Interest 2 for D2 }\end{array}$ & $\begin{array}{l}\text { Interest1 for D3 } \\
\text { interest2 for D3 }\end{array}$ \\
\hline State WRD & & & \\
\hline HydroEnergy, LLC. & & & \\
\hline Rivers-R-Us & & & \\
\hline Allen HOA & & & \\
\hline State Historic & & & \\
\hline Town of Allen & & & \\
\hline
\end{tabular}

- (15 min) Working break/networking and model exploration time

Participants should stay in role. You will need to direct the participants to think about "packages" of options for the Work Plan that address all three decisions. Ask the participants to propose packages that incorporate the ground rules they agreed to - while everyone's entitled to pursue their personal/organization's interests, they agreed to consider the interests of the whole group. Let the participants know that at the end of the break, you will ask them to propose different packages.

- (20 min) Brainstorming of Work Plan options

Ask the participants to brainstorm and propose different packages. Each package should include an option for each decision. The goal is to get several packages up on the board/flip chart for discussion without judging any of them. The participants may be tempted to start evaluating individual packages but ask them to hold off. If all the options the participants suggest are very 
similar, for example all focused on Dam A, you can ask them to keep brainstorming other ideas. For example, "Are there any other possibilities that include other dams in the system?"

- (20 min) Discuss different options using the model

Invite the participants to discuss what they like about different packages and what they can't live with. Encourage the participants to use the model to evaluate different outcomes, even though it only covers some interests. Eliminate packages without support or champions.

- (15 min) First non-binding vote and continued discussions

Ask the participants to raise their hand if they support each remaining package. Remind the participants of the ground rule that if they disagree with a proposal, they accept responsibility to offer an alternative to accommodate their own interests and those of others.

- (15 min) Second non-binding vote and continued discussions

- Final vote; Negotiation ends 


\section{Facilitator's Reporting Sheet}

Group \#:

Did your group reach agreement (yes or no)?

\# stakeholders in agreement ( 6 or 7$)$ :

If 6 , who did not agree?

Decision 1: Which dams should be included in the "Work Plan" and what alternatives should be considered for those dams?

\begin{tabular}{|c|c|c|c|c|c|c|}
\hline & Check one & & & & & \\
\hline Option 1: only Dam A & & & Dam 2 & \multirow{2}{*}{$\begin{array}{l}\text { Dam } 3 \\
\text { do nothing }\end{array}$} & \multirow[t]{2}{*}{$\operatorname{Dam} A$} & \multirow{2}{*}{$\begin{array}{l}\text { Dam B } \\
\text { do nothing }\end{array}$} \\
\hline $\begin{array}{l}\text { Management } \\
\text { alternative for each } \\
\text { dam }\end{array}$ & & do nothing & do nothing & & & \\
\hline $\begin{array}{l}\text { Option 2: Dam A with } \\
\text { other dams }\end{array}$ & & \multirow[t]{2}{*}{ Dam 1} & \multirow[t]{2}{*}{ Dam 2} & \multirow[t]{2}{*}{ Dam 3} & \multirow[t]{2}{*}{$\operatorname{Dam} A$} & \multirow[t]{2}{*}{ Dam B } \\
\hline $\begin{array}{l}\text { Management } \\
\text { alternative for each } \\
\text { dam }\end{array}$ & & & & & & \\
\hline \multicolumn{7}{|c|}{ Decision 2: How should the Work Plan be implemented? } \\
\hline & Check one & \multicolumn{5}{|c|}{ Conditions and Stipulations (if any) } \\
\hline \multicolumn{7}{|l|}{$\begin{array}{l}\text { Option 1: High-Level } \\
\text { Group }\end{array}$} \\
\hline \multicolumn{7}{|l|}{$\begin{array}{l}\text { Option 2: Collaborative } \\
\text { Study Group }\end{array}$} \\
\hline \multicolumn{7}{|l|}{ Option 3: Dam Owner(s) } \\
\hline \multicolumn{7}{|c|}{ Decision 3: Who pays to implement the Work Plan? (list funding sources \& amounts) } \\
\hline
\end{tabular}




\section{Pearl River Negotiation Simulation: Negotiating the Future of Dams Confidential Instructions for Federal Agency of Natural Resources (Federal ANR)}

Top Priority Interests ( 5 stars indicate the highest priority)

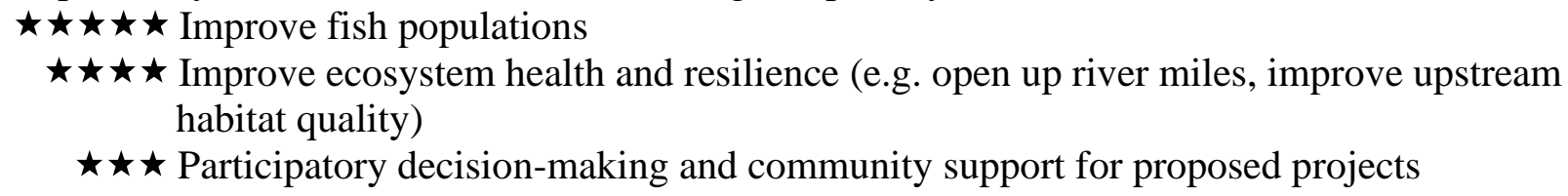

You are here to represent the Federal Agency of Natural Resources. Our mission and top priority is to fund coastal ecosystem restoration projects that provide benefits to species of significance, particularly sea-run fish species (fish that migrate between saltwater habitats and freshwater habitats to spawn). Typically, we prioritize restoring fish populations that are currently depleted but of high ecological and commercial value. Dams are barriers to fish passage and good quality habitats and dams should be removed strategically and proactively to provide net societal and fish population benefits. Today's meeting is an important restoration opportunity that should not be missed!

Our second priority is to enhance ecosystem resilience in the wake of climate change, which includes reducing vulnerability to storms and flooding and improving floodplain management. Dams are liabilities that make communities more vulnerable to flooding and removing dams is one way to make communities more resilient. We use the following additional criteria to prioritize our funding of projects:

- the willingness of local municipalities to contribute toward the overall project cost

- the level of community and public support for the project and interest in the issue

- the extent to which the project contributes to the scientific body of knowledge and improves the public's trust in science, and

- the project's potential to engage students and the public in education and outreach

The process for implementing the Work Plan should fit our goal of restoring as much of the ecosystem as possible.

We will not dedicate funds to projects where there is significant opposition from the public or the community is simply not ready to have a discussion about removing its dam(s). And, while we are interested in river restoration and are strong supporters of dam removals, we are skeptical of innovative funding options that simply mitigate damage caused elsewhere and do not lead to significant improvements to the environment.

We are willing to support a Work Plan today under the following conditions:

- The Work Plan must lead to significant improvements in fish habitat, passage and populations.

- At least five other participants must agree to the final Work Plan, including the Water Resources Division (State WRD).

- You are confident decisions will be informed by the best available science. Our knowledge base comes from the hundreds of successful projects we've worked on. We must have a role in selecting credible consultants (this includes providing input into the Request for Proposals). 


\section{We are willing to help fund implementation of the Work Plan under the following} additional constraints:

- You are confident that the group implementing the Work Plan has a commitment to dam removal or significant fish passage improvements.

- If the Work Plan will lead to significant fish passage benefits, even thought it removes no dams, we can provide up to $\$ 1,000,000$

- If the Work Plan will lead to significant fish passage benefits and includes dam removal, we can provide up $\$ 2,000,000$

- If the Work Plan includes fish passage improvements on Dams 1, 2, 3, we expect HydroEnergy, LLC. to pay for them (or at least contribute significant funding). We want to avoid the use of public funding to finance private benefit.

While we'd prefer to see all dams in the basin removed, we must be careful not to squander public funding on unrealistic projects or litigation, which is why we may consider fish passage installation or even doing nothing on some of the dams. However, we don't want to see hydropower dams relicensed if they have low fish passage and bring in little revenue.

Lastly, remember that this negotiation could be a great game-changing opportunity for us to advance our interests and come up with innovative solutions!

Your preferences for each of the three decisions are summarized in the worksheet on the next page. Please use the worksheet to brainstorm ideas for the Work Plan, such as which dams should be included and what alternatives should be considered for those dams (you can write them down in the spaces provided). 


\section{Preference Worksheet for Federal Agency of Natural Resources (Federal ANR)}

My Preference for Each Decision

Decision 1: Which dams should be included in the "Work Plan" and what alternatives should be considered for those dams?

\begin{tabular}{|c|c|c|c|c|c|c|c|c|c|}
\hline & \multirow{2}{*}{ model) } & \multirow[b]{3}{*}{ yes } & \multirow[b]{3}{*}{ yes } & \multirow[b]{3}{*}{ yes } \\
\hline & Dam 1 & Dam 2 & Dam 3 & Dam A & Dam B & & & & \\
\hline My Preferred Alternative & Remove & Do nothing & Fish lift & Remove & Remove & & & & \\
\hline \multicolumn{10}{|l|}{ Other Alternative } \\
\hline \multicolumn{10}{|l|}{ Other Alternative } \\
\hline \multicolumn{10}{|l|}{ Other Alternative } \\
\hline \multicolumn{10}{|l|}{ Other Alternative } \\
\hline \multicolumn{10}{|l|}{ Other Alternative } \\
\hline \multicolumn{10}{|l|}{ Other Alternative } \\
\hline Other Alternative & & & & & & & & & \\
\hline
\end{tabular}

Other Alternative

\section{Decision 2: How should the Work Plan be implemented?}

\begin{tabular}{|c|c|c|}
\hline & $\begin{array}{l}\text { Your Ranking of Each } \\
\text { Option } \\
(1=\text { strongest preference) }\end{array}$ & Conditions and Stipulations (if any) \\
\hline $\begin{array}{l}\text { Option 1: High-Level } \\
\text { Group }\end{array}$ & 1 & $\begin{array}{l}\text { - If federal funds are used to support the Work Plan, be sure the Town of Allen is moving toward removal of Dam A and does not intend to use the process } \\
\text { to delay making a decision. } \\
\text { - Even if we're contributing significant funds, we prefer State WRD be the on-the-ground manager as they have experience leading local projects in the state } \\
\text { and can foster community support for the final decision. However, we will lead implementation of the Work Plan if it will lead to significant benefits for } \\
\text { ecosystem restoration (assuming the dam owners are on board). }\end{array}$ \\
\hline $\begin{array}{l}\text { Option 2: Collaborative } \\
\text { Study Group }\end{array}$ & 2 & $\begin{array}{l}\text { - We will support this option IF we are confident the Town of Allen is moving toward dam removal. Decisions should be made collaboratively with diverse } \\
\text { stakeholders \& local communities involved in the process (and broadly supportive of the final decision). But, we also don't want community participants to } \\
\text { use the process as a delay tactic or for dam removal opponents to have more voice than others. } \\
\text { - If this option is selected, the Group should include an official representative from the Town of Allen and should be informed, first and foremost, by the } \\
\text { best available science. Local knowledge should be included. }\end{array}$ \\
\hline Option 3: Dam Owner(s) & 3 & $\begin{array}{l}\text { - This is the only option we can support if the group decides to repair Dam A without making any improvements to fish passage and river restoration. } \\
\text { - We cannot contribute funding to a project that does not meet Federal ANR's mission. }\end{array}$ \\
\hline
\end{tabular}

\section{Decision 3: Who pays to implement the Work Plan?}

- If the Work Plan will lead to significant fish passage benefits, but does not remove any dams, we can contribute up to $\$ 1,000,000$.

- If the Work Plan will lead to significant fish passage benefits and includes dam removal, we can contribute up $\$ 2,000,000$.

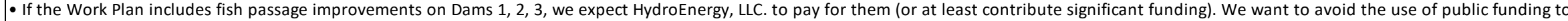

finance private benefit. 


\section{Pearl River Negotiation Simulation: Negotiating the Future of Dams}

\section{Confidential Instructions for Allen Pond Homeowner Association (Allen HOA)}

Top Priority Interests (5 stars indicate the highest priority)

$\star \star \star \star \star$ Maintain property values

$\star \star \star \star$ Maintain or improve pond-based recreation

$\star \star \star \star$ Maintain thriving waterfowl habitat

You are the chair of the local Homeowner Association (Allen HOA), and you are here today to represent hundreds of property owners along Allen Pond, located above Dam A on Mill Creek, a tributary of the Pearl River. The shallow impoundment created by this town-owned dam, referred to as "the Pond" by locals, sustains high quality waterfowl habitat (particularly for ducks and geese). Town residents, including waterfront property owners, only recently heard about the results of the inspection of Dam A and of the potential for it to be removed! Frustrated residents voiced their concerns at a local public hearing.

We understand this working group could have an important role in determining the future of Dam A and the Pearl River Basin dams. You are here to ensure the voices of property owners are incorporated into the process. While we are all for improving and restoring ecosystem function, we are concerned that removing Dam A or Dam B will result in reduced ecosystem function in this part of the watershed. And, members of the Allen HOA, as well as other property owners along the waterfront in this Town pay some of the highest taxes in town. Allen HOA members are concerned that if Dam A is removed and Allen Pond destroyed, property values will decrease and the Town will lose one of its primary recreation areas, which has been bringing tourist dollars to the Town of Allen and the state. We do not believe that removing this dam is in the best interest of the Town, and in our opinion, this dam should be repaired. We understand the Town is concerned about high repair costs for this dam. We think that maybe HydroEnergy, LLC. could retrofit Dam A for hydropower to reduce the cost to the Town. This would allow the hydropower company to increase its hydropower capacity, the property owners along Allen Pond to maintain their property values, and the town to continue to hold onto its prominent public recreation area.

The Allen HOA prefers to keep Dam A, especially if we can find a way to partner up with HydroEnergy, LLC. and assess whether it is feasible for them to purchase Dam A, repair it, and retrofit it for hydropower. While we have looked into the possibility of rezoning our waterfront homes to create a Village District, based on the experiences of nearby towns, we don't expect this would generate significant revenue to fund repair and maintenance of Dam A.

If the State WRD collaborates with us early in the process, we may be willing to evaluate the feasibility of using other resources to help fund fish passage installation (as long as Dam A is not removed and we receive assistance from the federal government and/or Rivers-R-Us). We prefer to keep Dam B because we are worried that removing Dam B will increase the pressure to remove Dam A. We have no preference about what happens to Dams 1, 2, and 3.

Lastly, we believe the perspectives of waterfront property owners and those concerned with preservation of industrial history are often excluded from the process, which is why we would like to see a study conducted of Dam A's social, cultural, and economic value. 
We are willing to support a Work Plan today under the following conditions:

- A representative from the Allen HOA must be included in the decision-making process and in all upcoming meetings regarding Dam A. This means the group would have to agree to a thorough public participation process as part of the Work Plan.

- Any feasibility study about Dam A and Dam B should include a sub-study focused solely on the social/economic/cultural values surrounding the two dams.

Lastly, remember that this negotiation could be a great game-changing opportunity for us to advance our interests and come up with innovative solutions!

Your preferences for each of the three decisions are summarized in the worksheet on the next page. Please use the worksheet to brainstorm ideas for the Work Plan, such as which dams should be included and what alternatives should be considered for those dams (you can write them down in the spaces provided). 


\section{Preference Worksheet for Allen Pond Homeowner Association (Allen HOA)}

\section{My Preference for Each Decision}

\section{Decision 1: Which dams should be included in the "Work Plan" and what alternatives should be considered for those dams?}

\begin{tabular}{|c|c|c|c|c|c|c|c|c|c|}
\hline & & & & & & (use model) & \multirow[b]{3}{*}{ yes } & \multirow[b]{3}{*}{ yes } & \multirow[b]{3}{*}{ yes } \\
\hline & Dam 1 & Dam 2 & Dam 3 & $\operatorname{Dam} A$ & Dam B & & & & \\
\hline My Preferred Alternative & Do nothing & Do nothing & Do nothing & Repair, hydro, fish nature-like fish ladder & Do nothing & & & & \\
\hline \multicolumn{10}{|l|}{ Other Alternative } \\
\hline \multicolumn{10}{|l|}{ Other Alternative } \\
\hline \multicolumn{10}{|l|}{ Other Alternative } \\
\hline \multicolumn{10}{|l|}{ Other Alternative } \\
\hline \multicolumn{10}{|l|}{ Other Alternative } \\
\hline \multicolumn{10}{|l|}{ Other Alternative } \\
\hline Other Alternative & & & & & & & & & \\
\hline
\end{tabular}

\section{Decision 2: How should the Work Plan be implemented?}

\begin{tabular}{|c|c|c|}
\hline & $\begin{array}{l}\text { Your Ranking of Each } \\
\text { Option (1 = strongest } \\
\text { preference) }\end{array}$ & Conditions and Stipulations (if any) \\
\hline $\begin{array}{l}\text { Option 1: High-Level } \\
\text { Group }\end{array}$ & 3 & $\begin{array}{l}\text { - Federal ANR will likely lead implementation if Dam A is to be removed or fish passage is to be installed, and the process will be easier if fewer parties are } \\
\text { involved. }\end{array}$ \\
\hline $\begin{array}{l}\text { Option 2: Collaborative } \\
\text { Study Group }\end{array}$ & 1 & $\begin{array}{l}\text { - You want to be included in decision-making about Dam A. } \\
\text { - You believe that if other stakeholders are talking about removing Dam A, then this Study Group is your best chance to ensure your voice is heard. } \\
\text { - You want homeowners to be represented. }\end{array}$ \\
\hline Option 3: Dam Owner(s) & 2 & $\begin{array}{l}\text { - This is an option only if the group decides to repair Dam A without making any improvements to fish passage or river restoration in general - if the group picks } \\
\text { this option, you don't think Federal ANR or Rivers-R-Us will be involved anyway. } \\
\text { - You are fine with the Town of Allen implementing the Work Plan, if the decision is to repair Dam A. Decisions should be made locally, especially when they } \\
\text { impact local communities. }\end{array}$ \\
\hline
\end{tabular}

\section{Decision 3: Who pays to implement the Work Plan?}

- You do not have any funds to pay to cover project costs.

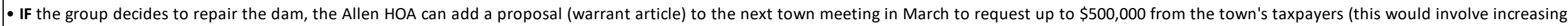

the local tax rate, so there is no guarantee the residents would pass the warrant article).

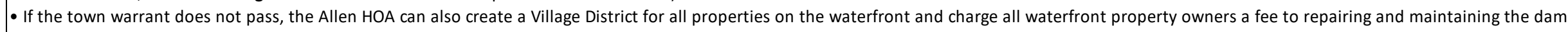

(although neighboring towns demonstrate that this option would not generate enough funds.

- IF the group decides to repair the dam, install hydropower turbines, and add fish passage, then we anticipate that HydroEnergy LLC. would help fund the project. 


\title{
Pearl River Negotiation Simulation: Negotiating the Future of Dams
}

\author{
Confidential Instructions for Historic Preservation Agency of the State (State \\ Historic)
}

Top Priority Interests (5 stars indicate the highest priority)
$\star \star \star \star \star$ Preservation of historic resources
$\star \star \star \star \star$ Participatory and transparent decision-making (specifically early involvement of historic interests in the process)
You represent the Historic Preservation Agency of the State and speak at today's meeting on behalf of both our Agency and the Town of Allen Heritage Commission (TAHC), who reached out to us ensure their interests are also considered in today's meeting. We operate under Section Z of the National Historic Values Act, which requires all federally funded projects to take into account possible impacts on historic resources through a consultation process. As you know, your job involves: 1) identifying any potentially significant historic resources, 2) assessing possible adverse effects of the proposed project, 3) avoiding, minimizing, or in the worst cases, mitigating loss of historic resources, and 4) balancing the public interest of historic preservation with other public benefits by involving the public in the process.

While we acknowledge that the health of our environment is vital to human society and an important factor in any decision, we want to make sure stakeholders and the public understand the value and significance of both pre-industrial and industrial historic resources in our state. We do not believe that historic preservation and river restoration are mutually exclusive goals. In addition, TAHC wants us to communicate its interest in preserving Allen's industrial history by preserving Dam A and its historic role in building Allen's economy and work force. Last week, after hearing about Dam A's potential removal, TAHC learned Dam A is eligible for nomination to the National Historic Registry due to its unique early/mid 1800s craftsmanship and historic contribution to the local economy. TAHC has started the nomination process. Based on preliminary data from the archeological consultant regarding the historic significance of Dam A, it is likely that Dam A's nomination will be accepted to the Registry.

Although Dam A is considered historic, you should be aware that only $1 / 2$ of the rock- and concrete-made wall abutting Dam A (which will be impacted if the dam is removed) is over 50 years old, which means that we consider only half of the dam to be historic. We are therefore worried that pro-removal parties (such as Rivers-R-Us) will use this information to advocate for removal. We should consider how the loss of historic resources around Dam A (if it is removed) might be mitigated, and be open to mitigation options such as preserving part of the dam (maybe the older parts of the abutting wall), interpretive signage, museum exhibits, or other proposed options.

We should clarify that while State Historic cannot "officially" take a position on what should be done with Dam A, we have been asked to take a position (and cast a vote on the Work Plan) on behalf of TAHC. Our top priority is to assist with the Section $\mathrm{Z}$ permitting process, ensure historic interests are involved early in the process, and lastly, ensure historic resources are preserved to the fullest possible extent and are given their due throughout this decisionmaking process. 
You should voice our concern that not all possible dam alternatives have been considered, and that fish passage benefits related to Dam A may have been overestimated. Dam removal appears to be the only option this group is seriously considering! We are concerned that there are no proposals to fund the potential repair and retrofit of Dam A. We propose that, as part of the final Work Plan, this group commit to exploring options for establishing a funding mechanism dedicated to repairing dams with strong community, economic, and historic significance.

We are willing to support a Work Plan today under the following conditions:

- State Historic and TAHC must be actively included in the decision-making process and all upcoming meetings regarding Dam A. State Historic wants to see a thorough public participation and stakeholder engagement process, particularly one that includes historic interests, as part of the Work Plan. We will not support any Work Plan that includes removal of Dam A unless a strong collaborative process (option 2 under decision 2) is part of the Plan.

- If a collaborative implementation process is selected, we want "consulting party status" under Section $\mathrm{Z}$ review, which will give us greater control over historic mitigation and allow us to propose our own options for mitigating the loss of historic significance associated with Dam A (if it is removed).

- State Historic is very reluctant to support removal of Dam A, but can support dam removal on a case-by-case basis if there is evidence of significant fish passage benefits and if TAHC and State Historic are included early in the process. State Historic and TAHC want to see evidence of claimed fish passage benefits, since in the past there has been controversy over the science of establishing historic fish populations (particularly salmon).

Lastly, remember that this negotiation could be a great game-changing opportunity for us to advance our interests and come up with innovative solutions!

Your preferences for each of the three decisions are summarized in the worksheet on the next page. Please use the worksheet to brainstorm ideas for the Work Plan, such as which dams should be included and what alternatives should be considered for those dams (you can write them down in the spaces provided). 


\section{Preference Worksheet for Historic Preservation Agency of the State (State Historic)}

\section{My Preference for Each Decision}

Does the Alternative Address My Interests?

Preserve historic resources

\section{Decision 1: Which dams should be included in the "Work Plan" and what alternatives should be considered for those} dams?

\begin{tabular}{|l|l|l|l|l|}
\hline & Dam 1 & Dam 2 & Dam 3 & Dam A \\
\hline My Preferred Alternative & Do nothing & Do nothing & Do nothing & Repair \\
\hline Other Alternative & & & & \\
\hline Other Alternative & & & & \\
\hline Other Alternative & & & & \\
\hline Other Alternative & & & & \\
\hline Other Alternative & & & & \\
\hline Other Alternative & & & & \\
\hline Other Alternative & & & & \\
\hline
\end{tabular}

\begin{tabular}{|l|l|}
\hline Dam B & \\
\hline Do nothing & \\
\hline & \\
& \\
\hline & \\
\hline & \\
\hline
\end{tabular}

Decision 2: How should the Work Plan be implemented?

\begin{tabular}{|c|c|c|}
\hline & $\begin{array}{l}\text { Your Ranking of Each } \\
\text { Option (1 = strongest } \\
\text { preference) }\end{array}$ & Conditions and Stipulations (if any) \\
\hline $\begin{array}{l}\text { Option 1: High-Level } \\
\text { Group }\end{array}$ & 3 & $\begin{array}{l}\text { - You don't support this option. If the group decides to impair historic resources by removing or retrofitting dams, a Collaborative Study } \\
\text { Group (option 2) should guide the lead funding agency. } \\
\text { - If the group decides to repair Dam A and make no changes to the other dams, Federal ANR wouldn't be involved anyway. }\end{array}$ \\
\hline $\begin{array}{l}\text { Option 2: Collaborative } \\
\text { Study Group }\end{array}$ & 1 & $\begin{array}{l}\text { - This is your preferred option IF any of the dams are considered for removal or retrofit. Decisions should be made collaboratively with } \\
\text { diverse stakeholders and local communities should be involved in the process. } \\
\text { - We want to be an active member of the Study Group from the very beginning. We also want TAHC to be a member of this Study Group. } \\
\text { State Historic and TAHC should be appointed "consulting parties" to ensure we have an active role in historic preservation. }\end{array}$ \\
\hline Option 3: Dam Owner(s) & 2 & $\begin{array}{l}\text { - This is your preferred option IF the group decides to simply repair Dam A without making any improvements to fish passage or river } \\
\text { restoration. } \\
\text { - If repair of Dam A is the only alternative being considered, the municipality should lead the process in consultation with State Historic and } \\
\text { TAHC throughout the process to ensure historic resources are protected during dam repair/reconstruction. }\end{array}$ \\
\hline \multicolumn{3}{|c|}{ Decision 3: Who pays to implement the Work Plan? } \\
\hline $\begin{array}{l}\text { - We do not have any fur } \\
\text { - We are willing to provid } \\
\text { Values Act). }\end{array}$ & $\begin{array}{l}\text { ing to contribute tow } \\
\text { technical support to }\end{array}$ & $\begin{array}{l}\text { he Work Plan. } \\
\text { ify historic resources at project sites (the lead funding agency will still need to hire a consultant to address Section Z of the National Historic }\end{array}$ \\
\hline
\end{tabular}




\section{Pearl River Negotiation Simulation: Negotiating the Future of Dams Confidential Instructions for HydroEnergy, LLC.}

Top Priority Interests (5 stars indicate the highest priority)

$\star \star \star \star \star$ Hydroelectricity generation

$\star \star \star$ Reduce uncertainty $\&$ costs related to the upcoming relicensing process

As you know, you are the owner of HydroEnergy, LLC., a medium-sized firm focused on utilizing existing dam infrastructure to generate electricity for local communities and the region. In today's meeting you represent your interests as a hydropower dam owner and operator, with the goal of improving equity and efficiency in the hydropower relicensing process. HydroEnergy, LLC. owns three hydroelectric dams on the main stem of the Pearl River for which the 5-year relicensing process will soon start. As a company, we are proud of being able to supply power to local communities and contribute toward enhancing the economic vitality of this region.

HydroEnergy, LLC. sees dams as potential liabilities that can be turned into assets for communities and the state. Although we are not fond of large dams that impound hundreds of thousands of acres and displace many people, small and medium-sized dams, such as the many mill dams in the region, are good candidates to be repaired and retrofitted. These dams can then generate electricity and provide recreational opportunities and a reliable tax base from waterfront properties to the municipality. Our company believes small and medium-sized hydropower production will help the towns of Allen, Crisp, and Merk, as well as the state make significant progress toward sustainability. We say this because we are concerned about the negative perception many people have of hydropower dams. People want electricity and energy whenever they need it, but often do not understand what it takes to develop the power to meet their daily needs. We want people to understand that dams are not the only reason fish populations are declining and habitat is being lost. Other factors, such as climate change, development, pollutants and habitat fragmentation from roads, also contribute to declining ecosystem function. When environmentalists talk about river restoration, we believe they should be more holistic in their thinking and include these other factors as well. HydroEnergy, LLC. is here to help communities meet their energy demands in a sustainable manner and collaborate with others who want to take a holistic perspective toward river restoration.

Our primary interest is to use existing dam infrastructure for hydropower production. Our secondary interest is to improve the relicensing and decision-making process around hydropower dams to ensure a more reasonable cost of developing and operating hydropower facilities. We believe the rules and restrictions by which hydropower dam owners have to abide are too stringent and inefficient. We believe the administrative timeline of the relicensing process is too long and impedes renewable energy production in the state. Therefore, we prefer a process that doesn't elevate the voice of special interest environmental groups, such as Rivers-R-Us, in dam decisions in the Pearl River basin and in the upcoming relicensing discussions. While we are in support of an inclusive process, we do not believe that special interests should run the show.

We also understand that as part of next year's relicensing process for Dams 1, 2, and 3, our company will likely have to commit to very costly improvements to Dam 1, which makes us wonder whether the estimated improvements (fish passage improvements costing $\$ 1,500,000-\$ 2,000,000$ and dam repair costing up to $\$ 1,000,000$ ) are cost effective in the long-run. Additionally, we know that we have to 
"play nice” with Federal ANR and Rivers-R-Us during today's meeting if we want to maintain our credibility with them during next year's relicensing. This means that if we agree to install hydropower turbines on Dam A, we will likely have to agree to improving fish passage on Dam A as well (although we shouldn't have to bear the full cost of improvements on Allen's failing dam).

We are also interested in any option that improves fish passage on Dam 1 because it will reduce the likelihood that stakeholders will ask us to remove the dam as part of the upcoming relicensing process (a serious concern for us as dam removal advocates seem to have the ear of the relicensing agency where coastal dams are concerned). We are particularly interested in options in which other stakeholders contribute to funding fish passage improvements on Dam 1, as that will help reduce our anticipated future costs for Dam 1 (associated with relicensing).

\section{If our interests are met, our company will help fund implementation of the Work Plan under the following constraints:}

- We can contribute up to $\$ 2,000,000$ if we can maintain our existing hydropower capacity/revenue (or close to it) and offset project costs related to future maintenance/upkeep of Dam 1.

- We can contribute up to $\$ 1,000,000$ if we can increase hydropower capacity/revenue by adding turbines to Dams A and B, as this lower level of funding will allow us to fund anticipated future relicensing-related repairs for Dam 1.

Lastly, remember that this negotiation could be a great game-changing opportunity for us to advance our interests and come up with innovative solutions!

Your preferences for each of the three decisions are summarized in the worksheet on the next page. Please use the worksheet to brainstorm ideas for the Work Plan, such as which dams should be included and what alternatives should be considered for those dams (you can write them down in the spaces provided). 
Preference Worksheet for HydroEnergy, LLC.

\begin{tabular}{|c|c|c|c|c|c|c|c|}
\hline \multirow{2}{*}{\multicolumn{6}{|c|}{ My Preference for Each Decision }} & \multirow{4}{*}{$\begin{array}{l}\text { Cost of } \\
\text { Alternative } \\
\text { (use model) }\end{array}$} & \multirow{2}{*}{$\begin{array}{c}\text { Does the Alternative } \\
\text { Address My Interests? } \\
\text { Hydroelectricity } \\
\text { generation (use model) }\end{array}$} \\
\hline & & & & & & & \\
\hline \multicolumn{6}{|c|}{ Decision 1: Which dams should be included in the "Work Plan" and what alternatives should be considered for those dams? } & & \multirow[b]{3}{*}{ increase } \\
\hline & Dam 1 & Dam 2 & Dam 3 & $\operatorname{Dam} A$ & Dam B & & \\
\hline My Preferred Alternative & Do nothing & Do nothing & Do nothing & Repair, hydro, fish nature-like fish ladder & Do nothing & & \\
\hline Other Alternative & & & & & & & \\
\hline Other Alternative & & & & & & & \\
\hline Other Alternative & & & & & & & \\
\hline Other Alternative & & & & & & & \\
\hline Other Alternative & & & & & & & \\
\hline Other Alternative & & & & & & & \\
\hline Other Alternative & & & & & & & \\
\hline Decision 2: How should & the Work Plan be in & plemented & & & & & \\
\hline & $\begin{array}{l}\text { Your Ranking of Each } \\
\text { Option (1 = strongest } \\
\text { preference) }\end{array}$ & Conditions ar & tipulations (if & & & & \\
\hline $\begin{array}{l}\text { Option 1: High-Level } \\
\text { Group }\end{array}$ & 1 & $\begin{array}{l}\text { - This is your } \\
\text { - You want } t \\
\text { - As the dam } \\
\text { decision. }\end{array}$ & $\begin{array}{l}\text { eferred optio } \\
\text { xpedite the } r \\
\text { vner, you will }\end{array}$ & $\begin{array}{l}\text { he process will be easier if fewer parties are } \\
\text { nsing process (this is very important to you) } \\
\text { nvolved in any decision that includes Dams }\end{array}$ & $\begin{array}{l}\text { involved. } \\
\text {, so if this opt } \\
1,2 \text { and } 3 \text {, so }\end{array}$ & $\begin{array}{l}\text { ieves this goal } \\
\text { n't have strong }\end{array}$ & $\begin{array}{l}\text { ou support it. } \\
\text { eelings about this }\end{array}$ \\
\hline $\begin{array}{l}\text { Option 2: Collaborative } \\
\text { Study Group }\end{array}$ & 3 & $\begin{array}{l}- \text { Stakeholde } \\
\text { relicensing D } \\
\text { want federal } \\
\text { down the pro } \\
\text { - If this is th } \\
\text { best availabl } \\
\text { - You see thi }\end{array}$ & $\begin{array}{l}\text { ivolvement is } \\
\text { s } 1,2 \text {, and } 3 . \\
\text { encies to redu } \\
\text { ss (while also } \\
\text { otion the Wo } \\
\text { ngineering an } \\
\text { ption as an o }\end{array}$ & $\begin{array}{l}\text { ortant and you will go through the formal p } \\
\text { ever, this Study Group is an informal "add-c } \\
\text { he burden around relicensing, not create ar } \\
\text { king it more expensive). } \\
\text { Group selects today, you want to make sur } \\
\text { ientific expertise. } \\
\text { tunity to inform your upcoming relicensing }\end{array}$ & $\begin{array}{l}\text { ublic participa } \\
\mathrm{n} \text { " to the alre } \\
\text { informal Stuc } \\
\text { e you are part } \\
\text { process, partic }\end{array}$ & $\begin{array}{l}\text { ocess (as requi } \\
\text { nplicated and } \\
\text { p that increas } \\
\text { Study Group t } \\
\text { for engaging M }\end{array}$ & $\begin{array}{l}\text { d by law) when you start } \\
\text { pensive process. You } \\
\text { the burden and slows } \\
\text { ensure it is guided by the } \\
\text { k and Crisp. }\end{array}$ \\
\hline Option 3: Dam Owner(s) & 2 & $\begin{array}{l}- \text { This is your } \\
\text { general - if th } \\
\text { - You are wil } \\
\text { business sen }\end{array}$ & $\begin{array}{l}\text { lly option IF t } \\
\text { rroup picks th } \\
\text { to partner } \mathrm{n}\end{array}$ & $\begin{array}{l}\text { roup decides to repair Dam A without maki } \\
\text { tion, you don't think Federal ANR will be in } \\
\text { the Town of Allen to install turbines on eith }\end{array}$ & $\begin{array}{l}\text { g any improv } \\
\text { volved with fu } \\
\text { er Dams A or }\end{array}$ & $\begin{array}{l}\text { to fish passag } \\
\text { anyway. } \\
\text { th depending }\end{array}$ & what makes good \\
\hline Decision 3: Who pays tc & o implement the Wo & rk Plan? & & & & & \\
\hline $\begin{array}{l}\text { - We can contribute up to } \\
\text { - We can contribute up to } \\
\text { future relicensing-related } r\end{array}$ & $\begin{array}{l}\$ 2,000,000 \text { IF we can } n \\
\$ 1,000,000 \text { IF we can ir } \\
\text { repairs for Dam } 1 \text {. }\end{array}$ & $\begin{array}{l}\text { intain our ex } \\
\text { rease hydro }\end{array}$ & $\begin{array}{l}\text { g hydropon } \\
\text { er capacity/r }\end{array}$ & $\begin{array}{l}\text { pacity/revenue (or close to it) AND offset } \\
\text { ue by adding turbines to Dams A and B, as }\end{array}$ & $\begin{array}{l}\text { oject costs } \\
\text { nis lower lev }\end{array}$ & $\begin{array}{l}\text { future main } \\
\text { ding will allov }\end{array}$ & $\begin{array}{l}\text { ance/upkeep of Dam } 1 . \\
\text { s to fund anticipated }\end{array}$ \\
\hline
\end{tabular}




\section{Pearl River Negotiation Simulation: Negotiating the Future of Dams Confidential Instructions for Rivers-R-Us}

Top Priority Interests ( 5 stars indicate the highest priority)

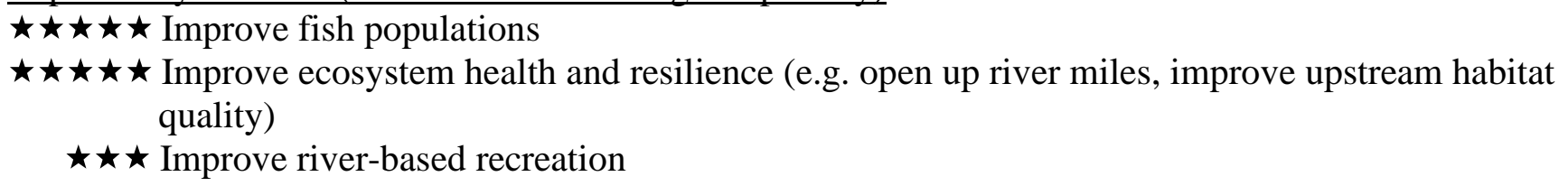

As you know we are a large non-profit, non-governmental organization whose main objective is to improve and restore the ecological function of the State's rivers, which includes improving and maintaining native species populations and habitat. Our NGO is concerned about the impacts dams have on the movement of both sea-run and cold-water species. In addition, we are concerned with the impacts of dams and their impoundments on water quality, wildlife habitat and recreation. Dams produce unnatural temperature fluctuations in the water, resulting in lower oxygen levels and negative impacts on vulnerable species. We support dam removal and other river restoration options (e.g. fish passage installation) by providing dam owners with grants to cover some costs.

In addition, we want more collaborative decision-making processes around dams. In particular, we want local communities to take a leadership role in dam removal and river restoration projects. From our experience with many dam projects, we've learned that for a project to succeed, the process must be participatory, transparent, collaborative, and informed by both the best available science and local knowledge. Strong partnerships with communities and stakeholders are the keys to successful dam removal projects. We realize river systems are complex, which is why we also care strongly about educating the public and stakeholders about the science behind river management.

As you know, we want to see all dams removed and have been advocating strongly for the removal of Dam 1. It's a coastal dam and the first barrier to sea-run fish on the Pearl River! We feel strongly that we will prevail and Dam 1 will be removed as a result of the upcoming hydropower relicensing discussions (and we are hopeful for other significant improvements in the Pearl River)! As for the Mill Creek dams, the removal of Dam A does not mean the loss of history. First, not everything that is historic is sacred and needs to be physically preserved to be remembered. Second, a dam can be removed and still have its historic characteristics preserved by keeping an old powerhouse or other features, and commemorating the dam through museum exhibits, library showcases and publications, plaques, interpretive signs, tours, lectures, and other tools. There are many possibilities!

We will always support a river restoration project, particularly one that embraces a systems perspective, but we do not have an unlimited budget. We also realize other stakeholders have different interests and we can be flexible on the Work Plan as long as it aligns with our core interests and goals. We are willing to support a Work Plan today under the following conditions:

- The Work Plan must significantly improve (1) fish passage and habitat and (2) ecosystem resilience.

- At least six of the seven stakeholders at the table need to support the final recommendation, including the dam owner. Support from the dam owner will ensure a commitment to action. We prefer that both the Town of Allen municipal representative and the Allen HOA representative 
support the Work Plan, as they represent the broader public, including property owners along the impounded water body who may otherwise drag out dam decisions.

- You are confident decisions will be informed by the best available science. We must have a role in selecting credible consultants, which includes providing input into the Request for Proposals.

We are willing to help fund implementation of the Work Plan under the following additional constraints:

- You are confident the community supports the Work Plan.

- If the Work Plan will lead to significant fish passage benefits, even thought it removes no dams, we can provide up to $\$ 500,000$

- If the Work Plan will lead to significant fish passage benefits and includes dam removal, we can give up $\$ 1,500,000$

Lastly, remember that this negotiation could be a great game-changing opportunity for us to advance our interests and come up with innovative solutions!

Your preferences for each of the three decisions are summarized in the worksheet on the next page. Please use the worksheet to brainstorm ideas for the Work Plan, such as which dams should be included and what alternatives should be considered for those dams (you can write them down in the spaces provided). 
Preference Worksheet for Rivers-R-Us

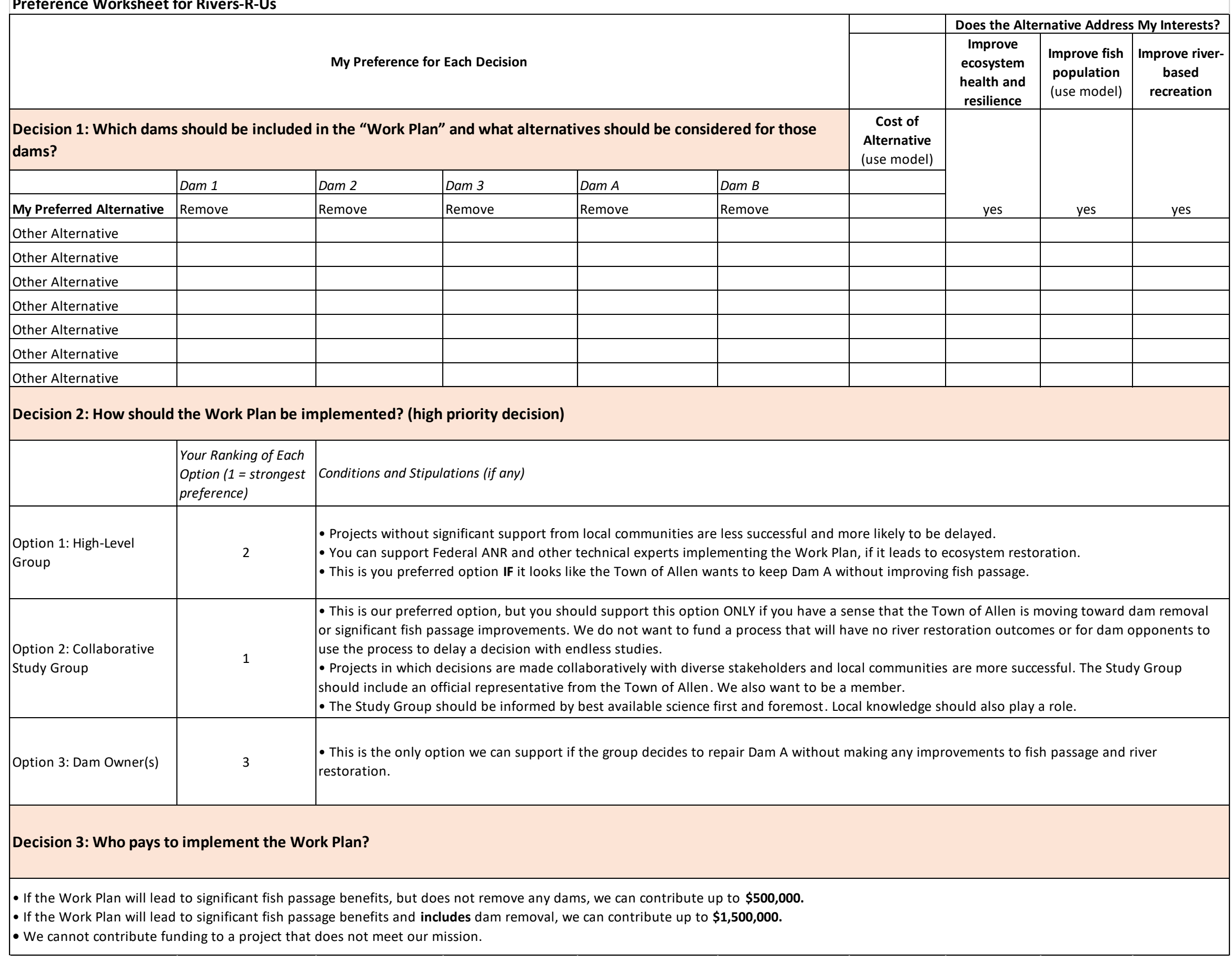




\title{
Pearl River Negotiation Simulation: Negotiating the Future of Dams
}

\section{Confidential Instructions for Town of Allen, Municipal Official}

Top Priority Interests (5 stars indicate the highest priority)

\author{
$\star \star \star \star \star$ Safety improvements related to Dam A \\ $\star \star \star \star$ Foster economic vitality \\ $\star \star \star \star$ Participatory and transparent decision-making
}

As the municipal official for the Town of Allen, you are pleased to see all these stakeholders come together to discuss the future of our dams, which will have an impact on our town for years to come. The Town of Allen owns two of the five dams in the Pearl River Basin (Dams A and B). Neither of our dams have fish passage, nor do they currently produce hydropower. Both are old mill dams and Dam A is a core feature of our town center. Dam B, which our local historians also consider historically significant, has no public access and is not visible from any public roads or properties. Dam A was recently issued a notice of public safety by the State Water Resources Division (State WRD), so first and foremost, we need to make sure we address this safety issue. Since Allen owns both dams, our taxpayers and residents (upstream and downstream of the dams, as well as those who do not live along the river) must be involved in the decision-making process, as they will likely have to contribute to funding whatever decision we make through property tax increases. While Allen is grateful for its thriving economic development, especially with our recent construction of a large shopping plaza, we have lost significant wetland acreage and our Conservation Commission is interested in the idea of using State WRD funds to mitigate this loss through innovative restoration projects.

Although the Town owns only two of the five Pearl River Basin dams, any decision on the management of town-owned dams should be a collaborative process with HydroEnergy, LLC., who is in the midst of a relicensing process for the three hydropower dams they own and operate. The Town believes this is a rare opportunity to collaborate with diverse stakeholders, establish private-public partnerships, and make innovative decisions that can benefit all parties, including our residents. We also have been collaborating closely with the City of Merk and the Town of Crisp.

In addition to addressing the safety issue around Dam A, our secondary interest is to ensure there is a fair and transparent decision-making process for all dams in our Town. We need to equitably represent the interests of our diverse residents (population: 15,000), including those who do not own property along Allen Pond. Part of a transparent decision-making process should include public participation and a neutral facilitator, which is why we want an involved, participatory, and equitable process. We want all residents to have the opportunity to voice their interests and perspectives. We also believe that both scientific/technical knowledge and local/indigenous knowledge should inform the final agreement. Since our town will likely contribute financially and dedicate significant staff and volunteer time to this project, we need to be confident all alternatives are fairly considered. The group at today's meeting should jointly hire a third-party consultant to work with us to collaboratively gather the needed data and information to help us make the best decision. Lastly, we want to reduce liability and the maintenance costs of our dams.

On one hand, we've heard from the Homeowner's Association (Allen HOA) that they want to keep Dam A; on the other hand, we heard from the Conservation Commission that they want to see the Dam A (and maybe even Dam B) removed. We need to consider these very different points of view. The 
Town does not have a preference for any particular decision alternative for our dams, as long as our residents have a fair say in the process, their concerns are incorporated into the final decision, and the Town's economic vitality continues to thrive into the future. Having said that, the Town also needs to consider other factors, including competing funding priorities, such as the proposed construction of a new high school in town (this would also involve raising the tax rate, and might compete with any dam-related town warrant article), and the potential fines associated with delaying a decision about Dam A. We hear the State WRD is impatient with our progress on responding about Dam A.

\section{We are willing to support a Work Plan today under the following conditions:}

- We ask that this decision-making process include a comprehensive feasibility study that provides options for what to do with Dam A, and that the feasibility study include a stakeholder assessment to identify affected parties and social issues. We know this will require public visioning forums and estimate it would cost around $\$ 10,000$ (if we hire a professional facilitator to lead the process).

- Since not all consultants value or have expertise in facilitating extensive public engagement, we need to make sure we include public involvement and close collaboration with the Town as key requirements in the Request for Proposals (RFP) when seeking consultants. The scope of the feasibility study should also include a broad range of community interests, such as economic development, aesthetics, recreation, and historic significance. Lastly, we want all products that come out of this Work Plan (e.g. studies, meeting minutes, etc.) to be available on the Town's website to make sure our residents have access to the information.

- If we decide to support repair of Dam A (or any other decision for that matter), there must be extensive public engagement (beyond the basic requirements) with diverse town residents, including those who do not live near or benefit from Allen Pond. Since the Town will have to acquire funds for Dam A via a town-wide warrant article (and the resulting increases in the tax rate) at our next March meeting, and since there are competing interests related to the warrant about Dam A, we feel that any warrant related to Dam A is more likely to garner broad support if there is extensive stakeholder engagement. An informed and involved public will lead to less uncertainty about the warrant, particularly if we engage the public early in the process. Therefore, in order for the Town to sign any Work Plan agreement, the Plan must include a collaborative study group (option 2 under decision 2).

Lastly, remember that this negotiation could be a great game-changing opportunity for us to advance our interests and come up with innovative solutions!

Your preferences for each of the three decisions are summarized in the worksheet on the next page. Please use the worksheet to brainstorm ideas for the Work Plan, such as which dams should be included and what alternatives should be considered for those dams (you can write them down in the spaces provided). 
Preference Worksheet for Town of Allen Municipal Official

My Preference for Each Decision

Decision 1: Which dams should be included in the "Work Plan" and what alternatives should be considered for those dams?

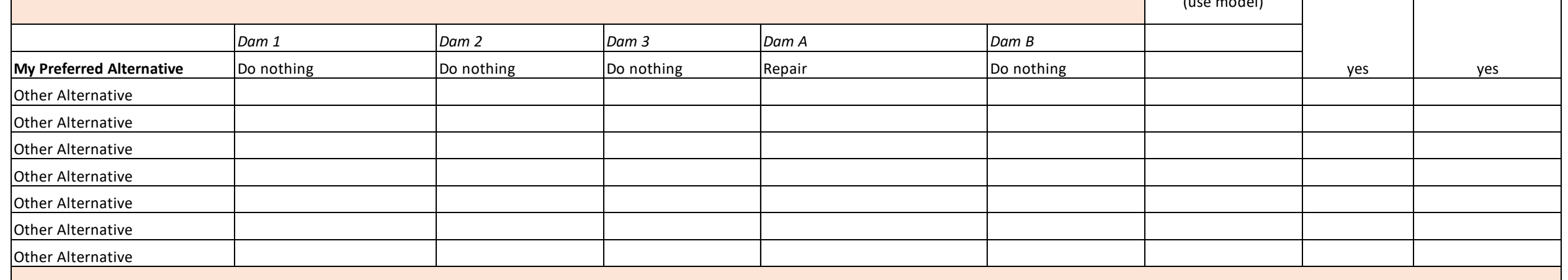

Decision 2: How should the Work Plan be implemented? (top priority decision)

\begin{tabular}{|c|c|c|}
\hline & $\begin{array}{l}\text { Your Ranking of Each Option } \\
(1=\text { strongest preference })\end{array}$ & Conditions and Stipulations (if any) \\
\hline Option 1: High-Level Group & 3 & $\begin{array}{l}\text { - You don't support this option. } \\
\text { - If the group decides to impact local historic resources by removing or retrofitting dams, there should be a Study Group to guide the lead funding agency. }\end{array}$ \\
\hline $\begin{array}{l}\text { Option 2: Collaborative Study } \\
\text { Group }\end{array}$ & 1 & $\begin{array}{l}\text { - This is your preference IF any of the dams are considered for removal or retrofit. The group MUST include this option for you to agree on the Work Plan. } \\
\text { - Decisions should be made collaboratively with diverse stakeholders and local communities should be involved in the process. Participatory and transparent } \\
\text { decision-making is VERY important to us, which is why you want a representative from the Town of Allen and perhaps the Allen HOA to be active members of the } \\
\text { Study Group from the very beginning. } \\
\text { - Successful public engagement on a project like this takes on average 4-5 years, and MUST include a neutral facilitator (that you must approve of) and a } \\
\text { stakeholder assessment. } \\
\text { - You want the consultant to have a strong focus on public engagement. }\end{array}$ \\
\hline Option 3: Dam Owner(s) & 2 & $\begin{array}{l}\text { This is your preferred option IF the group decides to simply repair Dam A without making any improvements to fish passage or river restoration in general. If repair } \\
\text { of Dam A is the only alternative being considered, you believe the municipality should lead the process and the role of state and federal government should be } \\
\text { minimal, unless they contribute funding. State WRD will also continue to be involved as they currently regulate Dam A and B. }\end{array}$ \\
\hline
\end{tabular}

\section{Decision 3: Who pays to implement the Work Plan?}

- You do not have any available funds to cover project costs.

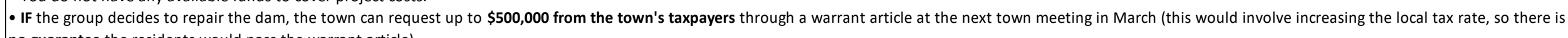
no guarantee the residents would pass the warrant article).

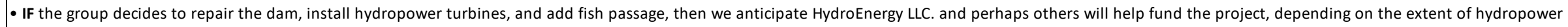
generation and fish passage improvements. 


\section{Pearl River Negotiation Simulation: Negotiating the Future of Dams}

\section{Confidential Instructions for State Water Resources Division (State WRD)}

\section{Top Priority Interests (5 stars indicate the highest priority)}

$\star \star \star \star \star$ Safety improvements

$\star \star \star \star$ Improve fish populations

$\star \star \star \star$ Improve ecosystem health \& resilience (e.g. open up river miles, improve upstream habitat quality)

You represent the State Water Resources Division, which convened today's meeting to discuss the status and future of dam decisions in the Pearl River Basin in response to interest expressed by the Town of Allen and other stakeholders. You are here today to ensure that any recommendations comply with State WRD's dam safety standards. As you know, State WRD is responsible for inspecting dams throughout the state, conducting dam safety inspections, classifying dams based on the level of risk they pose to downstream communities, permitting construction of new dams and reconstruction of existing dams, and lastly, coordinating with dam owners to resolve dam deficiencies and improve dam safety. Our dam classification work involves categorizing dams based on the risk they pose downstream if they fail. For example, a "High Risk" dam, which could cause loss of life, is regulated more stringently than a "Low Risk" dam, which might cause minor damage to private property if it were to fail. The State WRD also has a special program focused on river restoration and dam removals and has staff to assist dam owners with the process of dam removal for river restoration.

State WRD's primary objective is public safety. We don't want to see any dams fail due to inadequate attention, maintenance, and repair. It is important to us that objective data and scientific information inform the Work Plan as we want to see tax dollars used efficiently to further the public good. Our secondary objective is river restoration. We are largely opportunistic about dam removal projects, as State WRD does not target specific dams for removal. Instead, we help dam owners who wish to remove their dams learn more about the removal process, find funding and apply for permits. We should also mention that biologists from the State Department of Fish, Wildlife, and Natural Resources, who unfortunately have their annual conference today and are not able to attend this meeting, expressed their interest in improving aquatic organism passage and habitat quality on Pearl River and Mill Creek.

We realize and acknowledge that each dam project is unique and that there might be other interests and concerns at stake (e.g. property values, recreation, preservation of industrial history, water supply, etc.). We aim to collaborate with stakeholders to best address their concerns, while still meeting safety rules and regulations.

While the safety branch of the State WRD cannot advocate for specific dam management options over others (e.g. dam removal), officials from other State WRD branches would like to see Dams A and B removed to reduce liability and lower future maintenance costs. We can help dam owners apply for competitive state and federal grants to fund engineering, permitting, and construction phases of dam removal, as long as the project meets broader State WRD river restoration objectives. At a minimum, we expect these funds will cover the cost of removing Dam A and/or Dam B. 
We are willing to support a Work Plan today under the following conditions:

- The owners of any dam(s) included in the Work Plan support the proposal.

- The Work Plan must adequately address the safety issues identified in Dam A's inspection report, particularly because this is a "High Risk" dam. We are not interested in a "band aid" solution to long-term safety issues in our state.

\section{We are willing to help fund implementation of the Work Plan under the following additional constraints:}

- You are confident that the group implementing the Work Plan has a commitment to significant fish passage improvements.

- We can provide up to $\$ 500,000$ if you feel that all of our safety and river restoration interests are met in the Work Plan. If you think state funding would be better spent on other priorities, we will contribute less funding or none at all. Keep in mind that what we spend on this project reduces the funding available for other restoration opportunities around the state.

- If we contribute funding, you should insist that credible science inform future decisions and we have a role in selecting credible consultants (this including providing input the Request for Proposals).

Lastly, remember that this negotiation could be a great game-changing opportunity for us to advance our interests and come up with innovative solutions!

Your preferences for each of the three decisions are summarized in the worksheet on the next page. Please use the worksheet to brainstorm ideas for the Work Plan, such as which dams should be included and what alternatives should be considered for those dams (you can write them down in the spaces provided 


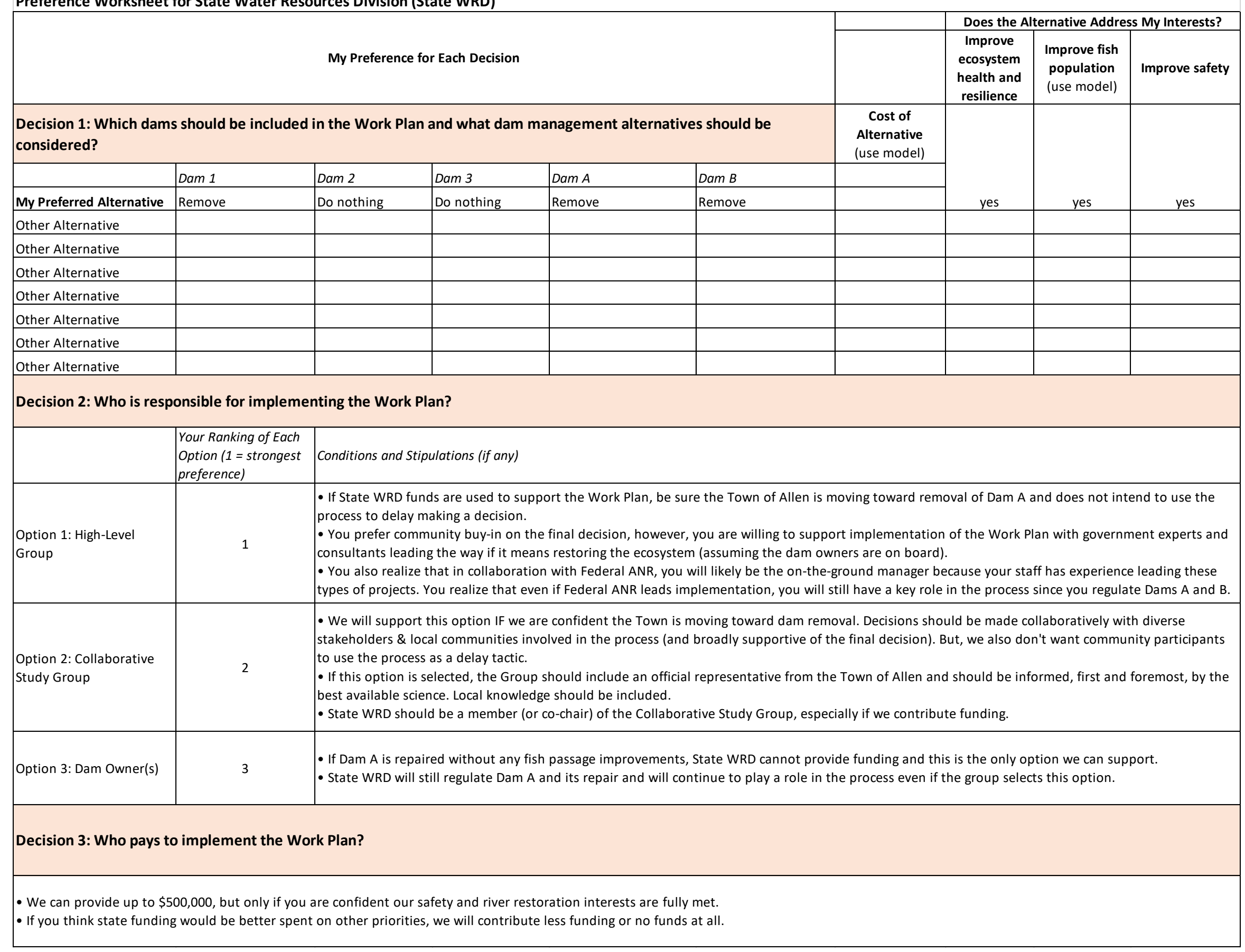


